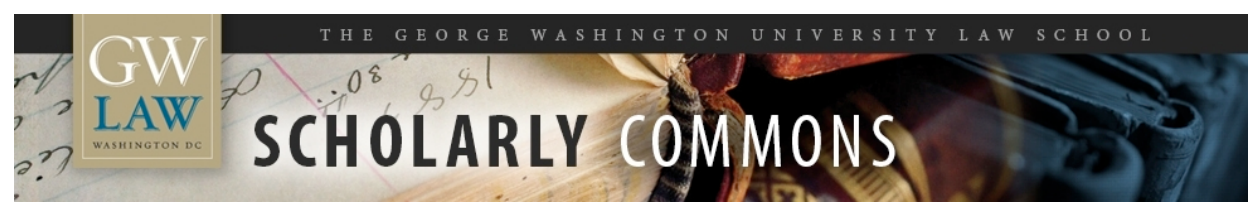

\title{
The Fourth Year of Forgetting: The Troubling Expansion of the Right to Be Forgotten
}

\author{
Dawn C. Nunziato \\ George Washington University Law School, dnunziato@law.gwu.edu
}

Follow this and additional works at: https://scholarship.law.gwu.edu/faculty_publications

Part of the Law Commons

\section{Recommended Citation}

RPS Submitter, GWU Law, The Fourth Year of Forgetting: The Troubling Expansion of the Right to Be Forgotten (2018). 39 U Pa J Int'I Law 1 (2018); GWU Law School Public Law Research Paper No. 2018-30; GWU Legal Studies Research Paper No. 2018-30. Available at SSRN: https://ssrn.com/abstract=

This Article is brought to you for free and open access by the Faculty Scholarship at Scholarly Commons. It has been accepted for inclusion in GW Law Faculty Publications \& Other Works by an authorized administrator of Scholarly Commons. For more information, please contact spagel@law.gwu.edu. 


\title{
THE FOURTH YEAR OF FORGETTING: THE TROUBLING EXPANSION OF THE RIGHT TO BE FORGOTTEN
}

\author{
DAWN CARLA NUNZIATO*
}

\begin{abstract}
In its famous "right to be forgotten" decision, the Court of Justice of the European Union ruled in 2014 that search engine operators must, upon request from a data subject, remove links that result from searches for an individual's name when those results are "inadequate, irrelevant or no longer relevant, or excessive in relation to the purposes... carried out by the operator of the search engine." The initial implementation of the right to be forgotten was limited in several ways. First, it was limited in geographical scope to European domains of search engines. Google-the primary search engine affected by the decision-limited delisting to its European domains (such as Google.es and Google.de) and refrained from implementing such delisting within its global Google.com search engine. While Google has consistently sought to limit the geographical reach of the right to be forgotten decision, European data regulators have insisted upon its global implementation. Second, the implementation of the right to be forgotten was limited to search engines and only imposed delisting requirements on the search engines; it did not extend to the underlying content at issue, such as newspaper archives or other online content. As such, the

* William Wallace Kirkpatrick Research Professor of Law, The George Washington University Law School; Co-Director, Global Internet Freedom Project. I am very grateful to the participants of the Global Network Initiative's Conference on Extraterritoriality and Global Threats to Free Expression and Privacy and the Goethe Institute's Conference on Privacy and Power, for their helpful comments on earlier drafts of this article. I am also very grateful to the editors of the University of Pennsylvania Journal of International Law, especially Margaret Ledak, and to Stuart Call, Alexia Khella, and Ken Rodriguez for providing excellent research and library assistance in connection with this article, and to Dean Blake Morant for financial support of my research.
\end{abstract}


right to be forgotten decision mandated only indirect - not directcensorship of the content to be forgotten.

Recently, however, European courts have expanded the scope of the right to be forgotten (and related privacy rights) to mandate how newspapers and other Internet content providers make available content on the Internet, in some instances requiring erasure or anonymization of such content. These expansions of the right to be forgotten have posed greater impositions on freedom of expression, including on the rights of United States citizens and members of the press to access information on the Internet regarding U.S. court decisions. In addition, the European Union's General Data Protection Regulation-which went into effect in May 2018imposes even greater infringements on the right to freedom of expression and does not accord the fundamental due process rights of notice or the opportunity to be heard to affected speakers and publishers. Furthermore, the right to be forgotten is expanding beyond Europe -- to countries such as India, Russia, Mexico, Japan, and Colombia -- and these countries are imposing expansive obligations on search engines and Internet content providers to censor information on the Internet.

While the right to be forgotten began as a right that was limited in scope-and had a limited effect on the free flow of information on the Internet-in the past four years it has rapidly expanded into a formidable global threat to freedom of expression.

\section{INTRODUCTION}

It all began in 2009 when a Spanish lawyer named Mario Costeja González did what many of us do and ran a search for himself on Google. Upon conducting the search, he came upon a newspaper article from 1998 in La Vanguardia, a popular Spanish newspaper that maintained an electronic news archive. The newspaper article referenced the forced sale at auction of Costeja González's property to pay for his social security debts. Costeja González was not happy with these search results and claimed that the article and its ready accessibility via a Google search violated his privacy rights under the European Union's Data Protection Directive.

Five years later, in May 2014, the Court of Justice of the European Union issued its decision in Costeja González's favor in the now-famous case of Google Spain SL v. Agencia Española de Protección de Datos ("Google Spain"). In what has become known as the 
"right to be forgotten" decision, the Court ruled that search engine operators like Google must, upon request from a data subject, remove links that result from searches for an individual's name when those results are "inadequate, irrelevant or no longer relevant, or excessive in relation to the purposes... carried out by the operator of the search engine." 1 In the years since the decision was handed down, Google has received requests from European data subjects to remove approximately two million links to web sites containing information about themselves and has granted over $43 \%$ of these requests. ${ }^{2}$

The initial implementation of the right to be forgotten in the immediate aftermath of the Google Spain case was limited in several ways. First, it was limited in geographical scope to European domains of search engines. Google - the primary search engine affected by the Google Spain decision-limited delisting to its European domains (such as Google.es and Google.de) and refrained from implementing such delisting within its global Google.com search. While Google has sought from the outset to limit the geographical scope of the decision, European data regulators have repeatedly insisted upon the expansion of the geographical reach of the decision, to render the delisting mandate applicable globally to all of Google's domains. Second, the Google Spain decision's remedy was limited to search engines and did not extend to the websites hosting the underlying content at issue, such as the newspaper archive that contained the article in the Google Spain case. In the case of Mario Costeja González, for example, although Mr. Costeja González requested that the Court order the newspaper to take down or anonymize the article about him, the Court limited its ruling to ordering that Google delist the article upon a search for the data subject's name. As such, the Google Spain decision mandated only indirect-not direct-censorship of the content at issue, since the underlying content remained unaffected. Recently, however, European courts have expanded the scope of this and related privacy rights to mandate how newspapers and other content

12014 E.C.R. Case C-131/12, Google Spain SL v. Agencia Española de Protección de Datos and Mario Costeja González, 317, para. 94 [hereinafter Google Spain], available at http://eur-lex.europa.eu/legalcontent/EN/TXT/?uri=CELEX:62012CJ0131 [https://perma.cc/6X2F-6PCW].

2 European Privacy Requests for Search Removals, GOOGLE TRANSPARENCY REPORT (last updated June 19, 2017), https://www.google.com/transparencyreport/removals/europeprivacy/?hl=en [https://perma.cc/ZR79-XUHZ] (noting that 900,665 out of a possible 2,080,903 links to websites were delisted). 
providers make available the underlying content at issue on the Internet, in some instances requiring erasure or anonymization of the content in the news archives at issue. These expansions of the right to be forgotten have posed ever greater impositions on freedom of expression, including on the rights of United States citizens and members of the press to access information on the Internet regarding U.S. court decisions and proceedings involving European data subjects. In addition, the European Union's General Data Protection Regulation - which goes into effect in May 2018-will lead to even greater infringements on the right to freedom of expression and will not accord the fundamental due process rights of notice or the opportunity to be heard to affected speakers and publishers. To make matters worse, the right to be forgotten is expanding beyond Europe, to countries such as India, Russia, Mexico, and Japan, and these countries are imposing increasing obligations on search engines and the underlying websites at issue to remove information from the Internet. What began as a right that was limited in scope-and had a limited effect on the free flow of information on the Internet and United States citizens' right to access such information-has rapidly expanded in the years since the Google Spain decision to a formidable global threat to freedom of expression.

In Part I of this Article, I analyze the limited scope of the original right to be forgotten decision, emphasizing the ways in which that decision was confined in its scope and geographical reach. In Part II, I analyze a series of recent European privacy decisions that have expanded the breadth of the right to be forgotten and the associated right to privacy in several European countries and have disregarded the distinction the European Court of Justice drew between data controllers (who are subject to delisting obligations) and media sites (which are protected from delisting obligations by the right to freedom of expression and their journalistic privileges). In Part III, I examine the ongoing litigation between Google and the French Data Protection Authority over the geographical reach of the right to be forgotten. While Google has insisted that the European right to be forgotten should be geographically limited in its scope and implementation to searches involving and accessible by European data subjects, the French Data Protection Authority has insisted the European data protection laws extend extraterritorially, to all of Google's domains, and that Google must implement the delisting mandated by the European right to be forgotten on all searches conducted by everyone around the world, including on all searches on Google.com. In Part IV, I examine the recently 
adopted General Data Protection Regulation - the successor to the 1995 EU Data Protection Directive - and the ways in which this Regulation, which became effective in May 2018, further strengthens the ability of individuals to remove information about themselves from the Internet, to the detriment of Internet users' free speech and due process rights. Finally, in Part V, I canvass the expansion of the right to be forgotten beyond the European Union, to countries such as India, Russia, Mexico, Colombia, and Japan. I conclude by warning that, absent greater attention to these issues and absent the contraction of this rapidly expanding right to be forgotten, free speech on the Internet as we know it will continue to be imperiled.

\section{THE LIMITED SCOPE OF THE ORIGINAL RIGHT TO BE FORGOTTEN DECISION}

The Google Spain case originated in 2009, when Spanish attorney Mario Costeja González became aware that a Google search of his name returned links to a Spanish newspaper's 1998 electronic archives containing a notice about a real estate auction of his property connected with attachment proceedings for the recovery of his social security debts. ${ }^{3}$ Costeja González claimed that this search result from a Google search of his name was in violation of his rights under the EU Data Protection Directive, which requires that personal data only be processed by "data controllers" insofar as the data is adequate, relevant, and not excessive in relation to the purpose for which the data is collected and processed. ${ }^{4}$ Costeja González initiated proceedings against the newspaper La Vanguardia (in which the notice originally appeared) and against Google Spain and Google Inc. before the Agencia Española de Protección de Datos ("Spanish Data Protection Agency"). Costeja González advanced two arguments in these proceedings. First, he sought relief against the newspaper itself. Against the newspaper, he argued that the notice should either be removed by the newspaper from its electronic archive, altered so that his personal data no longer appeared in connection with the notice, ${ }^{5}$ or that the newspaper should employ technological means to direct search engines like

3 See Google Spain, supra note 1 at para. 14 (stating that Mr. Costeja González officially lodged his complaint on March 5, 2010).

4 Id. at para. 15

5 Id. 
Google to exclude the notice from its automatic indexing (by using exclusion protocols or codes such as "noindex" or "noarchive"). Second, he argued that Google Spain and Google Inc. should be required to remove links to the notice when a search was performed on his name. ${ }^{6}$

The Spanish Data Protection Agency rejected Costeja González's complaint against the newspaper La Vanguardia, holding that the publication of the notice was legally justified and indeed legally required by order of the Ministry of Labor and Social Affairs, which mandated the publication of the auction notice so as to secure as many bidders as possible on the foreclosure of Costeja González's home. ${ }^{7}$ Accordingly, the actual content regarding Costeja González's home foreclosure was not removed from the newspaper's website (and remains there to this day $^{8}$ ), and the Agency did not require the newspaper's website to implement technological means to prohibit the article from being indexed by search engines. But the Agency upheld the complaint against Google Spain and Google Inc., and required these search engines to stop linking to the La Vanguardia notice when Internet users conducted a search on Costeja González's name. ${ }^{9}$ Google Spain and Google Inc. brought actions challenging the Agency's decision before the Audiencia Nacional ("National High Court") of Spain, and that court stayed those proceedings and referred the relevant questions to the European Court of Justice. ${ }^{10}$

On the questions referred regarding the application of the EU Data Protection Directive, the ECJ reached several conclusions. First, the Court concluded that the search engine operators' activities fell within the scope of "processing personal data." 11 Second, it held that a search engine operator is a "data controller." 12 Third, it concluded that the Directive applied to search engines based outside of Europe like Google.com whose business operates and prof-

\footnotetext{
$6 \quad I d$.

7 Id. at para. 16 (noting that the Spanish Data Protection Agency rejected the complaint on July 30, 2010).

8 See Subhasta D'immobles [Auction of Properties], La Vanguardia, Jan. 19, 1998, at $23, \quad$ available
http://hemeroteca.lavanguardia.com/preview/1998/01/19/pagina-

23/33842001/pdf.html [https://perma.cc/2MKP-CUZE].

9 See Google Spain, supra note 1 at para. 17.

10 Id. at para. 18.

11 Id. at para. 41.

12 Id.
} 
its within Europe. ${ }^{13}$ Fourth, and importantly for our purposes, the Court drew a distinction between the processing of personal data carried out by search engines and the processing carried out by the publishers of websites like La Vanguardia. On this point, the Court concluded that search engine processing constituted "processing of personal data" by a "controller" within the meaning of the EU Data Protection Directive, but that the processing by the newspaper website itself did not. Further, the Court noted that processing by news websites fell within a separate category of processing "solely for journalistic purposes," which benefited from exemptions from the requirements of the Directive. The Court explained:

[T] he processing of personal data carried out in the context of the activity of a search engine can be distinguished from and is additional to that carried out by publishers of websites, consisting in loading those data on an internet page . . . [T] he activity of a search engine consisting in finding information published or placed on the internet by third parties, indexing it automatically, storing it temporarily and . . . making it available to internet users ... must be classified as 'processing of personal data' ... when that information contains personal data and, second, the operator of the search engine must be regarded as the 'controller' in respect of that processing ....

[In contrast,] the processing by the publisher of a web page consisting in the publication of information relating to an individual may, in some circumstances, be carried out 'solely for journalistic purposes' and thus benefit, by virtue of Article 9 of Directive 95/46, from derogations [or exceptions] from the requirements laid down by the Directive [including exemptions and protections for freedom of expression], whereas that does not appear to be so in the case of the processing carried out by the operator of a search engine. It cannot therefore be ruled out that in certain circumstances the data subject is capable of exercising the [EU's data protection] rights . . . against that operator but not against the publisher of the web page. ${ }^{14}$

Thus, while the European Court of Justice in its Google Spain decision imposed de-listing obligations on search engines under the

13 Id. at para. 60.

14 Id. at paras. 35, 85 (emphasis added). 
Directive, it declined to impose any obligations on newspaper websites themselves in light of the protections that the Directive recognizes for journalistic purposes and for the protection of freedom of expression.

On the basis of these provisions, the Court held that Google Inc. and Google Spain-but not the newspaper website La Vanguardia-were bound by the Directive to process personal data of European data subjects only insofar as the processing was "adequate, relevant, and not excessive in relation to the purpose for which it is collected and/or further processed." 15 Therefore, the Court held, a data subject may require a search engine to remove information that does not comply with these requirements. ${ }^{16}$ The Court concluded:

[I]f it is found, following a request by the data subject . . . that the inclusion in the list of results displayed following a search made on the basis of his name of the links to web pages published lawfully by third parties and containing true information relating to him personally is, at this point in time, incompatible with . . the Directive because that information appears, having regard to all the circumstances of the case, to be inadequate, irrelevant or no longer relevant, or excessive in relation to the purposes of the processing at issue carried out by the operator of the search engine, the information and links concerned in the list of results must be erased. ${ }^{17}$

The Court, however, qualified its ruling by observing that, in certain cases, the public's interest in accessing information about an individual who has a role in public life may outweigh the data subject's interest in having the link removed. ${ }^{18}$ It noted that "[i]f it appeared, for particular reasons, such as the role played by the data subject in public life, that the interference with the [data subject's] fundamental rights is justified by the preponderant interest of the general public in having... access to the information in question," then the data subject's right to be forgotten request should not be granted and the links should not be removed. ${ }^{19}$ Accordingly, the Court established a balancing test pursuant to which the search engine operator is required to weigh the data subject's in-

15 Id. at para. 72.

16 Id. at para. 88.

17 Id. at para. 94 (emphasis added).

18 Id. at para. 97.

19 Id. 
terests in removal against the interests of the general public in accessing information of genuine import to the public. ${ }^{20}$ In applying its balancing test, the Court concluded that the interests of the general public in accessing the information about Costeja González in this case did not outweigh his interests in securing removal of this information. The Court explained: "[S]ince in the case in point there do not appear to be particular reasons substantiating a preponderant interest of the public in having, in the context of such a search, access to that information . . . the data subject may . . . require those links to be removed from the list of results." 21

On the issue of how exactly a search engine operator is to implement delisting requests from data subjects, the Court ruled that European data subjects have the right to approach the search engine operator directly with their delisting claims under the $\mathrm{Di}$ rective and that the search engines must then make a determination whether to grant or deny the delisting request. ${ }^{22}$ For this reason, the Court's decision does not merely provide a right of action for data subjects to bring in courts of law or before their country's Data Protection Authority; rather, it provides a right of action for data subjects to bring directly to the search engines themselves. Accordingly, the Court's Google Spain decision essentially charges search engines with the requirement of implementing a system for evaluating and complying with such right to be forgotten requests. As the Court explained, "the data subject may address such a request directly to the operator of the search engine (the controller), which must then duly examine its merits [and determine whether to grant or deny the request]." 23 The Court's decision requires search engines like Google to act as the decision maker to determine whether to grant or deny a data subject's delisting request in the first instance. ${ }^{24}$

The original right to be forgotten decision, as I explain above, was limited in several ways. Importantly, in reaching its decision, the European Court of Justice refused to impose any obligations on the underlying publisher of the information itself - La Vanguardia

\footnotetext{
$20 \quad$ Id. at para. 98.

21 Id.

22 Id. at para. 77.

23 Court of Justice of the European Union Press Release No 70/14, Judgment in Case C-131/12, Google Spain SL, Google Inc. v. Agencia Española de Protección de Datos, Mario Costeja González (May 13, 2014), available at http:/ / curia.europa.eu/jcms/upload/docs/application/pdf/201405/cp140070en.pdf [https://perma.cc/3AD8-MFHM].

24 Id.
} 
newspaper-holding that the newspaper was protected by the EU Data Protection Directive's exemptions and protections for freedom of expression, as the newspaper was processing the data subject's information "solely for journalistic purposes." 25 Recent European court decisions, however, have refused to recognize the Directive's-or similar national laws'-exemptions for newspapers' processing solely for journalistic purposes, and have imposed de-indexing, anonymization, and outright erasure obligations on newspapers and other internet publishers themselves. This trend poses increasing dangers for freedom of speech and freedom of the press online, as I examine below.

\section{EXPANSION OF THE RIGHT TO BE FORGOTTEN TO IMPOSE ERASURE AND ANONYMIZATION OBLIGATIONS ON NEWSPAPERS AND OTHER MEDIA WEBSITES}

Several European Courts have disregarded the exemption that the European Court of Justice recognized for newspaper websites' processing of data for journalistic and expressive purposes, and have imposed de-indexing, anonymization, and even erasure obligations on the newspapers themselves. In a decision handed down in October 2015, the Spanish Supreme Court (the court of last resort for non-constitutional matters) ruled that the right to be forgotten imposes obligations not just on search engines but on newspapers and publishers of the underlying content as well. ${ }^{26}$ The

25 See Google Spain, supra note 1 at para. 18 ("[T]he processing by the publisher of a web page consisting in the publication of information relating to an individual may, in some circumstances, be carried out 'solely for journalistic purposes' and thus benefit, by virtue of Article 9 of Directive 95/46, from derogations from the requirements laid down by the directive [including exemptions and protections for freedom of expression] ... It cannot therefore be ruled out that in certain circumstances the data subject is capable of exercising the rights referred to in Article 12(b) and subparagraph (a) of the first paragraph of Article 14 of Directive 95/46 against that [search engine] operator but not against the publisher of the web page.")

26 See S.T.S., Oct. 15, 2015 (J.T.S. No. 545/2015) (Spain) http://www.poderjudicial.es/search/contenidos.action?action=contentpdf\&data base-

match $=$ TS\&reference $=7494889 \&$ links $=\% 222772 \% 2 \mathrm{~F} 2013 \% 22 \% 20 \% 22545 \% 2 \mathrm{~F} 2015$

$\% 22 \&$ optimize $=20151019 \&$ publicinterface $=$ true [https: / / perma.cc/75CS-GKWY] (concluding that the right to be forgotten imposes obligations on newspapers and publishers in addition to search engines). 
Court held that such newspapers are required to adopt technical measures to exclude entire articles from being indexed by search engines, and to render the articles completely hidden and inaccessible via general search engines - not just upon the search of an individual's name (as was the effect of the Google Spain decision's mandate), but upon any search within any general search engine.

At issue in the Spanish Supreme Court case was the request by two former drug traffickers to render inaccessible a news article that the national newspaper El País had published in 1985 about their conviction and imprisonment through any type of search on general search engines like Google. ${ }^{27}$ The data subjects claimed that they had overcome their drug addictions, served their sentences, paid their debt to society, and returned to normal private and professional lives; and that therefore El País should be required to implement technical measures to prevent the webpage containing the article about them from being indexed by search engines in any manner, not just as a result of a search by their names (which is the relief that would be available to them against Google under the implementation of the Google Spain decision). The lower courts ruled in favor of the data subjects, and El País appealed to the Spanish Supreme Court.

In its argument to the Spanish Supreme Court, El País argued that its initial publication of the news article about the data subjects' conviction and sentence was legal, as was the continued processing and digitization of the article, and that its digital publication of the article was protected by the rights to freedom of expression and information under the European Convention of Human Rights. ${ }^{28}$ El País contended further that it should not be considered a "data controller" subject to the EU Data Privacy Directive's obligations, as transposed by Spain's implementing legislation. ${ }^{29}$

The Spanish Supreme Court rejected El Pais's arguments. The

27 See Brett Allan King, Spain High Court Issues First Right to Forget Ruling, Bloomberg Law: Privacy \& Data Sec., Oct. 28, 2015, (https://www.bna.com/spain-high-court-n57982062815/)

[https://perma.cc/Y8BY-P43J] (summarizing the case of former drug traffickers who claimed their right to be forgotten against El País).

28 Hugh Tomlinson, Case Law, Spain: A and B v Ediciones El País, Newspaper Archive to Be Hidden From Internet Searches but No "Re-writing of History", Inforrm's Blog, Nov. 19, 2015, https://inforrm.wordpress.com/2015/11/19/caselaw-spain-a-and-b-v-ediciones-el-pais-newspaper-archive-to-be-hidden-frominternet-searches-but-no-re-writing-of-history-hugh-tomlinson-qc/

[https://perma.cc/7DY4-RYJG].

29 Id. 
Court held, first, that the obligations that the relevant law imposed on data controllers extended not only to general search engines like Google, but also to El País to the extent that it was an operator of a news archives, because news archive operators had the technological ability to indicate to general search engines whether to exclude certain articles from such search engine's indexing, via the use of robot.txt code or metatags such as "noindex" or "noarchive." Second, the Court held that the continued processing by El País of these data subjects' personal data in its electronic news archive containing the subject article was no longer lawful under Spain's law implementing the EU Data Protection Directive, ${ }^{30}$ because the data could no longer be said to be "adequate, relevant and not excessive." 31 The Court reasoned that, while El País indeed enjoyed the protections under Article 10 of the European Convention of Human Rights, these protections extended primarily to the reporting of current affairs, not to the archiving of news. The Court explained that while the primary function of the press was to deliver news about current affairs, it was only a secondary task of the press to provide news archives to the public. Although the article at issue contained true facts about judicial proceedings and criminal convictions that occurred in the 1980s, time had rendered the further processing of the data by El País no longer "adequate, relevant, and not excessive." While El Pais's initial publication of the article about the data subjects' arrest and sentencing was justified, over time the processing of this data lost its justification, according to the Court. Thus, in balancing the newspaper's limited interest in maintaining a news archive containing this personal data against the damage to privacy and honor of the data subjects and their right to respect for their private lives, the latter interests outweighed the former. The Court held that, given that the data subjects were private figures and that there was no legitimate historic or public interest in their identities, the ongoing processing of their personal data was no longer justified. Accordingly, the Court ordered El País to implement technical measures to prevent the news

30 See id. (holding that the continued processing of the data subjects' personal data by the newspaper was illegal under Article 4 of Spain's Ley Organica 15/1999 de Proteccion de Datos de Caracter Personal (the Organic Law on the Protection of Personal Data), which transposed Article 6 of the EU Data Protection Directive. Article 6 of the EU Data Protection Directive describes the data quality requirements of scope of collection and use of data, adequacy and relevance of data collected in relation to purpose of use, accuracy of data, use of data for no longer than is necessary to accomplish the purposes for which it was collected).

31 Id. 
article at issue from being indexed by search engines such as Google and to render the content of the news article essentially inaccessible and invisible to the general public. ${ }^{32}$

German courts have ruled in a manner similar to the Spanish Supreme Court in the El País decision and have imposed obligations directly on the newspapers and publishers of Internet content to use technological measures to render certain articles inaccessible to the general public. The implications of one German court's ruling are even more problematic for free speech than the Spanish Supreme Court's decision discussed above, as this court has imposed such obligations on newspapers with respect to news articles involving public figures. In a recent case, the Highest Regional Court of Hamburg imposed obligations directly on a newspaper, despite the newspaper's argument that it was protected by the journalistic privilege recognized by the European Court of Justice under the European Union Data Privacy Directive. ${ }^{33}$ The German case involved the publication by a national German newspaper of various articles in 2010 and 2011 describing criminal proceedings against a well-known politician accused of being a pedophile. The accused data subject argued, inter alia, that the newspaper should be required to take measures to render the news articles about him inaccessible. Despite the fact that the data subject was a wellknown politician and public figure, the appellate court granted the plaintiff's claim that the newspaper implement technological measures to ensure that the subject articles could not be indexed by general search engines like Google. The court rejected the argument that the newspaper enjoyed a journalistic privilege to make the news article available and accessible in electronic formdeclining to recognize an important limitation of the European

32 Sebastian Schweda, "Right to be Forgotten" Also Applies to Online News Archive, Supreme Court Rules, 1 Eur. Data Protection L. ReV. 301, 302-03 (2015) (explaining that although the Spanish Supreme Court ruled in favor of the data subjects, the Court overturned two of the lower courts' rulings imposing obligations on El País. First, the Court reversed the requirement that El País delete the names of the plaintiffs in the article, and second, the Court reversed the requirement that El País prevent indexing of the article within its own news archive search functionality).

33 Hanseatic Oberlandesgericht, Hamburg, 7 Zivilsenat [OLG, Hamburg] [Higher Regional Court, Hamburg, 7th Civil Division] Jul. 7, 2015, 7 U 29/12 (Ger.) available at http://www.rechtsprechungham-

burg.de/jportal/portal/page/bsharprod.psml?doc.id=KORE217942015\&st=ent\& doctyp=juris-r\&showdoccase=1\&paramfrom $H L=$ true\#focuspoint [https://perma.cc/W5NY-SETA]. 
Court of Justice's Google Spain decision ${ }^{34}$ - and instead reasoned:

[I]f the operator of a search engine [like Google] may be obliged . . . to block the accessibility of certain online information upon a simple name search, this has to apply all the more to the originator of the information [the publisher or newspaper], regardless of whether or not he or she enjoys the press privilege. 35

As a result of these decisions by the Spanish Supreme Court and the Higher Regional Court of Hamburg, news articles about data subjects-including public figures like politicians-are no longer accessible to the general public, whether via a search on the names of the data subjects or via any other search on general search engines like Google. The implementation of the right to be forgotten by these courts goes well beyond the implementation contemplated under the Google Spain decision, which only mandated that general search engines like Google modify search results that appear upon the search of an individual's name. As Jonathan Zittrain explained regarding the limitations of the original Google Spain decision:

[T] he idea is not to remove certain indexed Web pages ... from a search engine entirely, but only [to remove] that which appears as a search result under [the data subjects'] names. So, a document called "Jonathan Zittrain foreclosure of 123 Main St." might be (if I were an EU citizen) ripe for removal as a result under "Jonathan Zittrain," but not under "123 Main St. foreclosure." 36

This limitation, however, no longer stands after the decisions of these courts. Because the courts ordered entire news articles regarding the data subjects to be rendered invisible to search engines like Google, the articles are no longer accessible by the general public via any search on a general search engine. As a result, after these decisions:

34 See text accompanying note 14 (discussing journalistic purposes exception to delisting requirement under the right to be forgotten).

35 Sebastian Schweda, Germany, Hamburg Court of Appeal Obliges Press Archive Operator to Prevent Name Search in Archived Articles, 1 EUR. DATA PROT. L. REV. 299, 300 (2015).

36 Jonathan Zittrain, Is the EU Compelling Google to Become About Me?, HARVARD Blogs: The FutURE OF THE INTERNET AND How TO STOP IT (May 13, 2014), http:/ / blogs.harvard.edu/futureoftheinternet/2014/05/13/is-the-eu-compellinggoogle-to-become-about-me/ [https://perma.cc/CN32-EPR9]. 
[S]earch engines [like Google] will be prevented from indexing the respective webpage or (in the case of the robots.txt file) the entire website altogether, not only limited to the indexing by the names of the plaintiffs. This means that the webpage cannot be found by any search engine ... effectively excluding the information contained in it from being accessed by anybody via an Internet search, regardless of the search term used. ${ }^{37}$

Courts in Belgium have gone even further than the courts in Spain and Germany in construing the right to be forgotten to impose obligations on newspapers and other publishers. In the 2016 Belgian case of Olivier G v. Le Soir, 38 the Belgian Court of Cassation (the court of last resort in Belgium) ordered a newspaper retroactively to anonymize the online version of an article it had published in 1994 concerning a fatal drunk driving accident caused by medical doctor Olivier G. The 1994 Le Soir article accurately described the doctor's role in the fatal accident, his conviction for drunk driving, and the death of two people involved. In 2008, the newspaper Le Soir made its news archives-including the 1994 article at issue - available and accessible online, such that a search for the doctor's name via a search engine or via the news archive's search function resulted in a link to the 1994 article. In 2010, the doctor-whose conviction was subject to a rehabilitation decision in 2006-requested that Le Soir anonymize the 1994 article to replace his name with the letter X. Upon the newspaper's refusal to anonymize the archived article, the doctor brought an action in the Belgian courts claiming that his right to privacy under Article 8 of the European Convention on Human Rights, ${ }^{39}$ and his concomitant

37 Schweda, "Right to be Forgotten", supra note 32 at 304.

38 Hof van Cassatie [Cass.] [Court of Cassation], 29 April 2016, AR C150052F, http:/ /www.cass.be https://inforrm.files.wordpress.com/2016/07/ph-vog.pdf [https://perma.cc/326M-8AN2].

39 See European Convention for the Protection of Human Rights and Fundamental Freedoms art. 8, Nov. 4, 1950, 213 U.N.T.S. 222 (entering into force Sept. 3, 1953, as amended by Protocol 11 (E.T.S. 155) which entered into force May 11, 1994) [hereinafter European Convention]. Article 8 provides:

“3. Everyone has the right to respect for his private and family life, his home and his correspondence.

4. There shall be no interference by a public authority with the exercise of this right except such as is in accordance with the law and is necessary in a democratic society in the interests of national security, public safety or the economic well-being of the country, for the prevention of disorder or crime, for the protection of health or morals, or for the protection of the 
right to be forgotten, were violated by the newspaper's refusal to anonymize the article, and that these rights outweighed the newspaper's rights under Article 10 of the European Convention to freedom of expression. ${ }^{40}$ The trial court sided with the doctor, as did the intermediate appellate court, ordering the newspaper to anonymize the subject article in its news archive.

On appeal to the Belgian Court of Cassation, the newspaper Le Soir argued that its right to freedom of expression protected its initial publication, as well as its subsequent archive, of the news article at issue. The Belgian Court of Cassation disagreed, holding that the right to be forgotten and associated privacy rights enshrined in Article 8 of the Convention (as well as in Article 17 of the International Convention on Civil and Political Rights or ICCPR ${ }^{41}$ ) provided a person who had been previously found guilty of a crime to object to elements of his criminal past being disclosed to the public and that this right justified limitations on the newspaper's right to freedom of expression. The Court held that, even though the 1994 article had been lawfully published by Le Soir at the time, its digital archiving constituted a new disclosure of the doctor's personal data that interfered with the doctor's right to be forgotten and his right of privacy under Article 8 of the European Convention and Article 17 of the ICCPR. In reaching this conclusion, the Court emphasized the fact that the doctor was a rehabilitated offender

rights and freedoms of others."

40 European Convention, supra note 39, art. 10 provides:

"1. Everyone has the right to freedom of expression. This right shall include freedom to hold opinions and to receive and impart information and ideas without interference by public authority and regardless of frontiers. ...

2. The exercise of these freedoms, since it carries with it duties and responsibilities, may be subject to such formalities, conditions, restrictions or penalties as are prescribed by law and are necessary in a democratic society, in the interests of national security, territorial integrity or public safety, for the prevention of disorder or crime, for the protection of health or morals, for the protection of the reputation or the rights of others, for preventing the disclosure of information received in confidence, or for maintaining the authority and impartiality of the judiciary.").

41 See International Covenant on Civil and Political Rights art. 17, Dec. 16, 1966, 999 U.N.T.S. 171 [hereinafter ICCPR] (providing that

" 1 . No one shall be subjected to arbitrary or unlawful interference with his privacy, family, home or correspondence, nor to unlawful attacks on his honor and reputation.

2. Everyone has the right to the protection of the law against such interference or attacks".). 
and a private figure, and that the accident had occurred over 20 years earlier. Balancing the newspaper's freedom of expression and right to create historically accurate archives against the doctor's right to privacy and right to be forgotten, the Court held that the doctor's rights to privacy and to be forgotten outweighed a strict respect for the newspaper's right to freedom of expression. In reaching its decision, the Court also recognized a troubling distinction between online and print journalism and held that freedom of expression and the journalistic privilege were more important in print than in online sources like Le Soir's electronic news archives. Accordingly, the Court held that the newspaper must remove all references to the doctor from the article in its online archives.

As a result of the decision of the Belgian Court of Cassation, the information about the doctor's drunk driving accident, arrest, and conviction are essentially erased from history by rendering the data subject anonymous, and such content can no longer be accessed by members of the public. ${ }^{42}$ The remedy ordered by this Court goes beyond the remedy ordered by the German and Spanish courts in the cases analyzed above, which left the underlying articles unmodified in the electronic news archives of the newspaper publisher. Indeed, the Spanish Supreme Court expressly overturned the part of the lower court's decision requiring that the newspaper redact the names of the plaintiffs in the original article, holding that a mandate that the newspaper edit or revise the underlying article was not an appropriate role for the court and would be tantamount to revising history. 43 The German court similarly ruled that an order requiring that the newspaper retroactively edit its earlier articles was improper and rejected plaintiff's request for this type of relief in that case. ${ }^{44}$ In contrast, the Belgian Court of Cassation failed to recognize the dangers of revising history and ordered the newspaper retroactively to anonymize the articles in question in its electronic news archives.

The Italian Supreme Court of Cassation has gone even further. In an unprecedented recent decision, the Italian Supreme Court of

\footnotetext{
42 Eric P. Robinson, Belgian Court Turns "Right to Be Forgotten" Into a Black Hole, BLOG L. ONLINE (July 19, 2016), http:/ / bloglawonline.blogspot.com/2016/07/belgian-court-turns-right-tobe.html [https://perma.cc/H8V2-AZPZ].

43 See Schweda, "Right to be Forgotten", supra note 32 at 302-03.

44 See Sebastian Schweda, Germany, Hamburg Court of Appeal Obliges Press Archive Operator to Prevent Name Search in Archived Articles, 1 EUR. DATA Protection L. Rev. 299, 300 (2015).
} 
Cassation has surpassed the obligations imposed on newspapers by the Spanish, German, and Belgian courts analyzed above and has ruled that a newspaper must delete in its entirety a truthful and accurate news article that was only two and a half years old and must pay damages to the complaining data subject for leaving the article on its news archives for this period of time. ${ }^{45}$ The Italian case began when newspaper publisher PrimaDaNoi printed an article in 2006 that truthfully and accurately described criminal proceedings that were brought against a local restaurant owner, which was undoubtedly a matter of public interest to the members of the community in which the restaurant was located. Two years after the publication of the article, the restaurant owner requested that the newspaper remove the article (notwithstanding the fact that the criminal proceedings against him were still ongoing), claiming that the article tarnished his reputation and damaged the image of his restaurant. When the newspaper refused to delete the article, the restaurant owner brought suit in the Court of Chieti at Ortona. That court held that, even though the article was only two years old and the criminal proceedings against the restaurant owner were still ongoing, the continued availability of the article in the newspaper's electronic archive was no longer justified by the newspaper's right to freedom of expression.

The newspaper appealed the lower court's decision to the Italian Supreme Court of Cassation, claiming that it enjoyed a journalistic privilege and right to freedom of expression to continue making the news article available in its electronic archives. The Italian Supreme Court disagreed, holding that the restaurant owner's right to privacy outweighed the right to freedom of expression and journalistic privilege of the newspaper. In particular, the Italian Supreme Court held that the public interest in the subject matter of the article had been satisfied by the availability and public accessibility of the article for two years. That public interest had "expired" and became outweighed by the right of privacy of the restaurant owner after two years. The Court explained:

The time passed between the date [the article] was first published and the date when its removal was requested sufficed to satisfy the public interest as far as its right to be informed was concerned, and... therefore, at least from the date when the formal notice [to remove the article] was re-

45 Cass., sez. un., 24 giugno 2016, n. 13161, Giur. it. 2016, II, 1 (It.) available at http://www.altalex.com/documents/news/2016/07/07/cronaca-e-diritto-alloblio [https://perma.cc/4ZUM-QRC9]. 
ceived, that data could no longer be disclosed [by the newspaper in its electronic news archive]. ${ }^{46}$

Accordingly, the Italian Supreme Court upheld the lower court's order mandating the complete erasure of the article from the newspaper's archive, holding that the news article had expired, "just like milk, yogurt, or a pint of ice cream." 47 In addition to mandating the complete erasure of the news article from the newspaper's digital archive, the Italian Supreme Court also upheld the portion of the lower court's order mandating that the newspaper pay damages in the amount of 10,000 Euros to the restaurant owner and the restaurant itself as a penalty for having kept the article accessible in its digital archives after the data subject had requested removal and for longer than was necessary to serve the public interest. In essence, the Italian Supreme Court granted the data subject an entitlement to determine the length of time for which the news article about him could remain accessible and the date after which it no longer served the public interest for the article to remain accessible in the newspaper's electronic archive.

The decisions of these Spanish, German, Belgian, and Italian courts upset the balance that the European Court of Justice initially carefully established between data subjects' privacy rights and newspapers' right to freedom of expression and journalistic privileges. While the European Court of Justice expressly refused to impose any de-indexing, anonymization, or erasure obligations on the underlying news websites themselves, these European court decisions have shown little to no solicitude for the journalistic privileges and free expression rights of newspapers, and have expanded the right to be forgotten and associated privacy rights in an unprecedented and troubling manner, to the detriment of the rights of freedom of expression and access to information online.

\section{GLOBAL IMPLEMENTATION OF THE EUROPEAN RigHT TO BE FORGOTTEN}

In the initial right to be forgotten decision, the European Court

46 See Athalie Matthews, How Italian Courts Used the Right to Be Forgotten to Put an Expiry Date on News, THE GUARDiAN (Sept. 20, 2016, 4:12 AM), https://www.theguardian.com/media/2016/sep/20/how-italian-courts-usedthe-right-to-be-forgotten-to-put-an-expiry-date-on-news [https://perma.cc/EJF76WXE].

47 Id. 
of Justice in Google Spain did not directly address the question of whether a data controller like Google must implement delisting decisions globally (for all searches on Google.com, for example) or merely within Europe (for searches on Google's European domains, like Google.es). While maintaining that search engines must provide "effective and complete protection" of data subjects' right to privacy, 48 and recognizing that the European Union sought to prescribe a broad territorial scope to its privacy protections, ${ }^{49}$ the Court did not speak directly to the question of whether search engines like Google must implement delisting only on their European domains or on all of their domains. When Google initially delisted the websites that Costeja Gonzalez requested that it delist, Google only removed them from its European country-specific versions of its search engine. The websites at issue, however, remained accessible on other versions of Google search, and, importantly, were available when a search was performed on the data subject's name on Google.com. Google's implementation of delisting only on its European domains was unsatisfactory to European data privacy regulators, which have demanded that Google implement the right to be forgotten globally, not just within Europe, and a protracted legal battle between Google and the European data privacy regulators - and in particular, the French data privacy regulator - has ensued.

Although the European Court of Justice itself was silent on the issue of the geographical reach of the delisting mandate, European data privacy regulators have insisted that Google (and other search engines) implement the right to be forgotten globally, on all of Google's domains, including Google.com, and not just within its European domains. First, in issuing guidelines within a few months of the European Court of Justice's right to be forgotten decision, the EU Article 29 Data Protection Working Partycomposed of all the Data Protection Authorities in the European Union-determined that the EU Data Protection Directive's priva-

48 See Google Spain, supra note 1 at para. 38 ("[T]he operator of the search engine as the person determining the purposes and means of that activity must ensure, within the framework of its responsibilities, powers and capabilities, that the activity meets the requirements of Directive 95/46 in order that the guarantees laid down by the directive may have full effect and that effective and complete protection of data subjects, in particular of their right to privacy, may actually be achieved.").

49 See id. at para. 54 (" $[\mathrm{I}] \mathrm{t}$ is clear... that the European Union legislature sought to prevent individuals from being deprived of the protection guaranteed by the directive and that protection from being circumvented, by prescribing a particularly broad territorial scope."). 
cy protections must be implemented globally and not just on data controllers' EU domains. 50 In November 2014, the EU Article 29 Working Party adopted a framework for the implementation of the original right to be forgotten decision-Guidelines on the Implementation of the Court of Justice of the European Union Judgment on "Google Spain and Google Inc. v. Agencia Española de Protección de Datos (AEPD) and Mario Costeja González" - in which the Working Party determined that in order to give full effect to the data subject's rights as defined in the European Court of Justice's ruling, de-listing decisions must be implemented in such a way as to guarantee full protection of data subjects' rights. The Working Party determined:

[D]elisting decisions must be implemented in such a way that they guarantee the effective and complete protection of data subjects' rights and that EU law cannot be circumvented ... [L]imiting de-listing to EU domains on the grounds that users tend to access search engines via their national domains cannot be considered a sufficient mean to satisfactorily guarantee the rights of data subjects according to the ruling. In practice, this means that ... de-listing should also be effective on all relevant domains, including .com. 51

Second, the French Data Protection Authority - The Commission Nationale de l'Informatique et des Libertés (CNIL) (the National Commission on Data Processing and Liberty) - has waged a protracted legal battle against Google in an attempt to require Google to implement the right to be forgotten globally, across all of Google's domains, including Google.com. As France's Data Protection Authority, CNIL is responsible for hearing matters in which data subjects claim that data controllers like Google have not properly protected their rights in making delisting and other data privacy decisions. One such data subject, Dan Shefet, a lawyer in Paris - who had prevailed in a defamation suit against another party - requested that Google remove links to websites that were alleged to be defamatory of him, not just on Google.fr and on

50 Article 29 Data Protection Working Party WP 225, Guidelines on the Implementation of the Court of Justice of the European Union Judgment on "Google Spain and Inc. v. Agencia Española de Protección de Datos (AEPD) and Mario Costeja González" C-131/12, 2014, 9 [hereinafter Article 29 Data Prot. Working Party Guidelines], http://ec.europa.eu/justice/data-protection/article29/documentation/opinion-recommendation/files/2014/wp225_en.pdf [https://perma.cc/YZ4R-7A7Y].

51 See id. (emphasis added). 
Google's other European domains, but globally, on Google.com. When Google refused to globally delist such sites, Shefet sought and obtained a court order from the Paris Tribunal de Grande Instance requiring that Google globally remove links to websites that were deemed to be defamatory of him, and threatening Google.com with a 1,000 Euro daily fine for noncompliance.52 When Google still refused to comply, Shefet sought the assistance of CNIL. CNIL had also received a number of complaints from other French data subjects who were not granted the delisting that they had requested from Google. Acting on Shefet's and other French data subjects' behalf, CNIL wrote a letter on April 9, 2015, to Google regarding what CNIL deemed to be Google's failure to fully implement its legal obligations under the European Court of Justice's Google Spain decision by not delisting the requested links from all of its domains. ${ }^{53}$

On April 24, Google responded that it would not change its practice of delisting only within its European domains. ${ }^{44}$ On May 21, CNIL informed Google that it had fifteen days to comply with delisting across all of its domains. 55 The notice indicated that if Google failed to comply with the order to delist globally within 15 days, CNIL's President would nominate a Rapporteur to draft a report recommending to the CNIL Select Committee that it impose sanctions on Google. ${ }^{56}$ On June 8, CNIL made public its Formal Notice to Google of its obligations to delist across all domains. ${ }^{57}$ On June 18, Google met with CNIL for clarification regarding what was required in order for it to fully comply with the delisting order. ${ }^{58}$ In July 2015, Google pushed back on the CNIL demand, and requested that CNIL withdraw its Formal Notice. ${ }^{59}$ After being

52 Owen Bowcott \& Kim Willsher, Google's French Arm Faces Daily €1,000 Fines Over Links to Defamatory Article, THE GUARDIAN (Nov. 13, 2014, 7:53 AM), https://www.theguardian.com/media/2014/nov/13/google-french-arm-finesright-to-be-forgotten [https:// perma.cc/ZH5G-ACLP].

53 Commission nationale de l'informatique et des libertés [CNIL] [National Commission on Data Processing and Liberty] Google, Inc., No. 2016-054, Mar. 10, 2016, 3 available

https:/ / www.legifrance.gouv.fr/affichCnil.do?oldAction=rechExpCnil\&id=CNIL TEXT000032291946\&fastReqId=273825503\&fastPos $=1 \quad$ [https://perma.cc/LFB8UHXL].

$54 \quad I d$.

$55 \quad I d$

$56 \quad I d$.

$57 \quad I d$.

$58 \quad I d$.

59 Id. 
granted an extension for compliance, Google requested an appeal of the order on July 30.60 The appeal was rejected on September 15, 2015, and on September 25, 2016, CNIL initiated legal proceedings against Google. 61

In March 2016, in an apparent attempt to compromise with CNIL, Google began implementing a plan of extending its delisting under the right to be forgotten beyond its EU-country level domains (like Google.fr), to all searches that appear to be conducted by European Union citizens on Google.com. ${ }^{62}$ Thus, under its extended implementation plan, if a French citizen conducted a search on Google.com, and if the search results included websites for which a French individual had requested delisting, Google would remove those websites from its search results for that search, even if the search were conducted on Google.com. As Google explained:

That means that if we detect you're in France, and you search for someone who had a link delisted under the right to be forgotten, you won't see that link anywhere on Google Search - regardless of which domain you use. Anyone outside the EU will continue to see the link appear on non-European domains in response to the same search query. 63

Not surprisingly, CNIL found this compromise measure to be insufficient and incomplete. The Commission's order on March 10, 2016, rejected Google's compromise position. In its order, CNIL explained:

Only delisting on all of the search engine's extensions, regardless of the extension used or the geographic origin of the person performing the search, can effectively uphold this right. The solution that consists in varying the respect for people's rights on the basis of the geographic origin of those viewing the search results does not give people effective, full protection of their right to be delisted. 64

CNIL provided further reasons in support of its conclusion that

$60 \quad I d$.

$61 \quad I d$.

62 Id.

63 Kent Walker, A Principle That Should Not Be Forgotten, Google BLoG (May 19, 2016), https://blog.google/topics/google-europe/a-principle-that-shouldnot-be-forgotten/[https://perma.cc/8ZCH-JCG3].

64 CNIL, supra note 53. 
Google's compromise position was insufficient, noting that (1) personal or professional contacts living outside of Europe could still access the delisted search result linking to content that may infringe the privacy of the person concerned; (2) personal or professional contacts living in Europe and using a non-European search engine extension (".com") with a non-French IP address could still access the delisted search result; and (3) the use of certain technical solutions by one conducting a search could easily get around Google's filtering system by allowing Internet users to change the geographic origin of their IP address. CNIL emphasized that the European Court of Justice's decision mandated "the effective application of the fundamental rights of the individuals involved, i.e. the right of privacy and protection of their personal data, with no possible circumvention," 65 and that Google did not adequately protect those rights by partial delisting on some geographic domains and not others. Referencing the Google Spain decision, CNIL contended, "it is clear... that the European Union legislature sought to prevent individuals from being deprived of the protection guaranteed by the Directive and [to prevent] protection from being circumvented, by prescribing a particularly broad territorial scope." 66 In essence, CNIL interpreted the European Court of Justice's reference to "broad territorial scope" as mandating worldwide delisting by search engines like Google. ${ }^{67}$ In addition, CNIL explained that the Court's requirement that "information in question no longer be made available to the general public" required nothing short of global delisting. While recognizing the potential conflict between European data subjects' privacy rights and the rights of Internet users throughout the world to access information on the Internet, CNIL was particularly dismissive of the latter and maintained that Google must implement delisting globally "without restriction, even if it conflicts with foreign rights," 68 like the rights of citizens of

65 Id. (emphasis added).

66 Id.

$67 \quad I d$.

68 Id. (emphasis added). This is not the first time that France has sought to impose its restrictions on Internet content globally, in a manner that conflicts with U.S. citizens' First Amendment rights. In the famous dispute between France and another U.S. Internet company, France objected when Internet search engine Yahoo! hosted an auction site in which it allowed its subscribers to auction off Nazi memorabilia. Under the French criminal law, it is illegal to "exhibit" in France public uniforms, insignias and emblems that "recall those used" by (1) an organization declared illegal in application of Article 9 of the Nuremberg Statute, such as the Nazi party, or by (2) a person found guilty of crimes against humanity. CODE PÉNAL [C. PÉN] [PENAL CODE] art. R645-1 (Fr.), makes it illegal to "wear or ex- 
other countries to access information on the Internet. CNIL further maintained that the Google Spain decision requires global delisting because once a company is considered a data processor within a country, all data processing activities of that company that stem from that country, regardless of where and in which domains they occur, are subject to the European data protection law. ${ }^{69}$ CNIL im-

hibit" in public uniforms, insignias and emblems which "recall those used" by (1) an organization declared illegal in application of Art. 9 of the Nuremberg Statute, or by (2) a person found guilty of crimes against humanity as defined by Arts. L211-1 to L212-3 or by the Law No 64-1326 of 1964-12-26. Two French groups devoted to combating racism and anti-Semitism sued Yahoo! in France, claiming that Yahoo!'s hosting auctions of Nazi memorabilia violated French criminal law. See Yahoo! Inc. v. La Ligue Contre le Racisme et l'Antisémitisme, 169 F. Supp. 2d 1181 (2001), rev'd, 433 F.3d 1199 (2006). In its defense, Yahoo! claimed that, while it was willing to abide by French law within France, and while it removed Nazi memorabilia from the French country-specific version of its site available at Yahoo.fr, it did not have the technological means to restrict only French users from accessing its auction site available at its internationally available site Yahoo.com. Id. at 1185. Furthermore, Yahoo! argued, such Nazi-related content was protected under the First Amendment, and therefore Yahoo! enjoyed the right to make such content available to U.S. citizens via its servers for Yahoo.com, which were hosted in the United States. Finally, and most importantly, Yahoo! asserted that France did not have jurisdiction over Yahoo!, a United States company whose servers were based in the United States. The French court disagreed with Yahoo!, and held that Yahoo! was in violation of French criminal law for hosting an auction of content that was illegal within France. It rejected Yahoo!'s argument that there was no feasible way for Yahoo! to restrict access to such content only within France and ordered Yahoo! to take all appropriate measures to deter and prevent access to auctions of Nazi memorabilia on its site by French residents within three months of the court's order or face a fine of 100,000 francs per day. While Yahoo! fought this order - for the next six years - in United States courts, along the way Yahoo! decided to cease hosting auctions of Nazi memorabilia within Yahoo.com. Accordingly, the practical effect of the French court's actions was to impose France's speech restrictions beyond its borders, on a U.S. company, where the speech subject to restriction was protected by the First Amendment, in violation of generallyaccepted foundational principles of international law regarding the limited geographical scope of a sovereign's laws.

69 CNIL emphasized in its order that the European Court of Justice in its Google Spain decision held that a company is subject to jurisdiction as a data processor within a country or territory "when the operator of a search engine sets up in a Member State a branch or subsidiary which is intended to promote and sell advertising space offered by that engine and which orientates its activity towards the inhabitants of that Member State." See Google Spain, supra note 1, at para. 20. Since Google met these requirements and is therefore considered a data processor within France, even though its processing may occur outside of France, CNIL contends that it is within its authority to require action by Google outside of France for all of the "processing associated with the 'Google Search' service." CNIL, supra note 53, at 7 ("[CNIL jurisdiction] therefore applies to all processing associated with the 'Google Search' service, since, within the meaning of Article 5-1-1 of the French Data Protection Act, Google France contributes, in French territory, to the activity of the search engine operator based in the United States, as stated in [Google Spain].") Finally, CNIL maintains that Google's differentiation between 
posed a financial penalty of 100,000 Euros against Google, Inc., for its continued failure to comply with CNIL's order. In May 2016, Google appealed CNIL's order to the France's Supreme Administrative Court (the Conseil d'État), which referred this question to the European Court of Justice. ${ }^{70}$

Google has sought to advance its legal position against the extraterritorial reach of the right to be forgotten in the court of public opinion, in France and throughout the world, as well as before the European Court of Justice. In explaining the broader legal principles at stake in the decision now pending before the Court, Google has argued on its blog, and in an open letter in the popular French magazine Le Monde, that a ruling in favor of CNIL would open the floodgates to worldwide censorship of Google results based on a single repressive country's laws:

We comply with the laws of the countries in which we operate. But if French law applies globally, how long will it be until other countries - perhaps less open and democraticstart demanding that their laws regulating information likewise have global reach? This order could lead to a global race to the bottom, harming access to information that is perfectly lawful to view in one's own country ... We have received demands from governments to remove content globally on various grounds - and we have resisted, even if that has sometimes led to the blocking of our services. ${ }^{71}$

In its arguments to the Court (and before the court of public opinion), Google correctly contends that countries should not be able to impose their laws on the Internet globally and should be required to limit the extraterritorial reach of their laws so as not to interfere with the political independence and sovereignty of other states, and that doing otherwise would quickly lead to a race to the bottom for Internet free speech. ${ }^{72}$ Although each country is enti-

domains is nothing more than a technical path differentiation, and that all of Google's processing across its many domains still occurs as part of one and the same processing system. Id. at 6 .

${ }^{70}$ See Alex Hern, ECJ to rule on whether 'right to be forgotten' can stretch beyond
EU, GHE GUARDIAN (July 2017), https://www.theguardian.com/technology/2017/jul/20/ecj-ruling-google-rightto-be-forgotten-beyond-eu-france-data-removed [https://perma.cc/6LUS-JDZN].

71 Kent Walker, A Principle That Should Not Be Forgotten, Google Blog (May 19, 2016), https://blog.google/topics/google-europe/a-principle-that-shouldnot-be-forgotten [https:/ / perma.cc/D5X4-H9BC].

72 The Republic of Turkey, for example, in the past has repeatedly urged Google to block access throughout the world to content that allegedly insulted the 
tled to determine what speech is protected and what speech is unprotected within its territory and in particular to determine how to balance the freedom of speech against individuals' right to privacy within its borders, countries do not and should not enjoy the power to implement their laws in ways that have an extraterritorial effect that spills over to restrict speech within other nations that have adopted different regimes for protecting speech. A foundational principle of national sovereignty is that each nation possesses full control over the affairs within its territorial, geographic boundaries. Under generally applicable international law principles, jurisdiction is a nation's assertion of power over the people, properties, and activities within its borders. According to this foundational principle of international jurisdiction:

The first and foremost restriction imposed by international law upon a State is that-failing the existence of a permissive rule to the contrary-it may not exercise its power in any form in the territory of another State. [Jurisdiction] cannot be exercised by a State outside its territory except by virtue of a permissive rule derived from international custom or from a convention. ${ }^{73}$

While nations enjoy the power to determine the substantive laws within their own territories, they generally do not enjoy the right to dictate laws that apply outside of their territories. Thus, any order issued by a national or regional court mandating that a search engine delist certain websites should be given effect only within the geographical boundaries of that country or region. As the United States Supreme Court recently emphasized, every nation must "avoid unreasonable interference with the sovereign authority of other nations" 74 and must ensure that the "potentially conflicting laws of different nations work together in harmony -a harmony particularly needed in today's highly interdependent

memory of its founder Mustafa Kemal Ataturk - a criminal offense in Turkey. Although Google blocked access to such content for Internet users in Turkey, Turkish officials apparently claimed that this country-specific blocking was insufficient to protect the rights of Turks living abroad and demanded that Google globally block access to content that insults the memory of Ataturk. Google properly refused to accede to this additional, overreaching request to export Turkey's laws to the rest of the world. See, e.g., ACCESS CONTROLlED: THE SHAPING OF POWER, RIGHTS, AND RULE IN CYBERSPACE 284-85 (Ronald Deibert, et. al. eds., 2010).

73 The Case of the S.S. Lotus (Fr. v. Turk.), Judgment, 1927 P.C.I.J., (ser. A.) No. 10, at 18-19 (Sept. 7).

74 F. Hoffman-La Roche Ltd. v. Empargran S.A., 542 U.S. 155, 164 (2004). 
commercial world." 75 This mandate of limiting the extraterritorial reach of one nation's laws reflects principles of customary international law. ${ }^{76}$ U.S. courts have long adhered to this presumption against extraterritorial application of our nation's laws in order to "protect against unintended clashes between our laws and those of other nations which could result in international discord."77 U.S. courts' adherence to this presumption has been consistently observed, even where the laws at issue sought to regulate conduct that was universally condemned, including crimes against humanity,78 and courts have held fast to the "presumption that United States law governs domestically but does not rule the world." 79 Indeed, the United States Supreme Court has applied the presumption against extraterritoriality in circumstances presenting a mere "risk of interference with a foreign nation's ability independently to regulate its own... affairs." 80

The Republic of France has also recognized the strong presumption against the extraterritorial application of one nation's laws. Indeed, in a recent amicus brief to the United States Supreme Court in the case of Morrison v. National Australia Bank Ltd.,81 the French government argued that "international comity counsels against expansive extraterritorial application" of one nation's laws,

75 Id. at 164-65. See also McCulloch v. Sociedad Nacional de Marineros de Honduras, 372 U.S. 10 (1963) (affirming the District Court ruling that Congress has the power to apply the National Labor Relations Act to foreign-flag vessels while they are in American waters); Romero v. Int'l Terminal Operating Co., 358 U.S. 354, 382 (1959) (holding that the Jones Act is applicable to "foreign events, foreign ships, and foreign seamen... in accordance with the usual doctrine and practices of maritime law."); Lauritzen v. Larsen, 345 U.S. 571, 578 (1953) (upholding the long-held maritime principle that an Act will not apply to foreigners with respect to acts they engage in outside the dominion of the sovereign state enacting).

76 See Restatement (THIRD) OF Foreign Relations LAW OF THE United STATES $\S \S 403(1), 403(2)$ (AM. LAW. INST. 1987) (limiting the unreasonable exercise of prescriptive jurisdiction with respect to a person or activity having connections with another State); Hartford Fire Ins. Co. v. Cal., 509 U.S. 764, 817 (1993) (Scalia, J., dissenting) (identifying rule of construction as derived from the principle of "prescriptive comity").

77 E.E.O.C. v. Arabian American Oil Co., 499 U.S. 244, 248 (1991).

78 See, e.g., Kiobel v. Royal Dutch Petroleum Co., 133 S. Ct. 1659 (2013) (holding that under the Alien Tort Statute, there is a presumption derived from a traditional canon of interpretation against extraterritorial application of U.S. law, which serves to protect against clashes between U.S. law and the law of other nations).

79 Microsoft Corp. v. AT\&T Corp., 550 U.S. 437, 454 (2007).

80 F. Hoffman-La Roche Ltd., supra note 74, at 165. (emphasis added).

81 Morrison v. Nat'1 Austl. Bank Ltd., 561 U.S. 247 (2010). 
especially where such extraterritorial application would "interfere with the sovereign authority of foreign nations." 82 Indeed, in its amicus brief in that case, the French Government emphasized the general principle of international law "by which one sovereign power is bound to respect the subjects and the rights of all other sovereign powers outside its own territory." 83 The French Government explained that the Restatement (Third) of Foreign Relations makes clear that nations should refrain from exercising their jurisdiction to prescribe when the exercise of such jurisdiction is "unreasonable," and that a key determinant of whether jurisdiction to prescribe is unreasonable is whether it would bring about "the potential for conflict with foreign law." 84 Where application of one nation's laws would "conflict with... the legal systems of other nations," exercise of such jurisdiction is unreasonable and improper within the meaning of the Restatement (Third) of Foreign Relations. ${ }^{85}$ Indeed, in its opinion in Morrison v. National Australia Bank $L t d$, the United States Supreme Court cited these arguments from the French Government's amicus brief in support of the Court's holding that the United States laws at issue did not have extraterritorial application because of the "probability of incompatibility with the applicable laws of other countries." 86

As discussed above, courts in the United States - and throughout the world - have been particularly careful to avoid extraterritorial application of national laws when doing so would conflict with the laws of other countries and the fundamental rights of citizens of other countries. ${ }^{87}$ Since the extraterritorial application beyond the European Union of the right to be forgotten and its delisting mandate would conflict with the laws of the United States and the First Amendment rights of U.S. citizens - as I explain in greater detail below - the French Conseil D'État should not order Google to implement the right to be forgotten globally.

Although the First Amendment does not mandate that every U.S. citizen has access to information about everyone else-and, indeed, provides much more limited protection to speech about private figures and matters of private interest than to speech about

82 Brief for the Republic of France as Amicus Curiae in Support of Respondents at 3, Morrison v. Nat'1 Austl. Bank Ltd., 561 U.S. 247 (2010).

83 Id. at 10.

84 Id. at 11.

85 Id.

86 Morrison v. Nat'l Austl. Bank Ltd., 561 U.S. 247, 269 (2010).

87 See text accompanying notes 74-80. 
public figures and matters of public interest ${ }^{88}$ - the right to be forgotten is currently being implemented by search engines like Google in the European Union in such a way that would be inconsistent with the First Amendment if Google were required by the French Conseil d'État to implement the right to be forgotten globally. In initially determining how to apply the European Court of Justice's mandate as issued in the Google Spain case-in which the Court had substantially deferred to Google on matters regarding which delisting requests to grant and which to deny-Google created the Google Advisory Council composed of a number of international free speech and privacy experts who advised the company in making its delisting decisions to take into account the data subject's role in public life (with private figures meriting greater privacy protection than public figures) and the nature of the information (i.e., whether the information related solely to private interests or to the public interest). The Council advised Google that it should be more inclined to grant delisting requests when made by private figures and when made regarding matters that were solely of private interest and less inclined to grant delisting requests when made by public figures and when made regarding matters of public importance. ${ }^{89}$ To the extent that Google only granted delisting requests when made by private figures on matters of private interest, the global implementation of the right to be forgotten would not necessarily be inconsistent with First Amendment rights of U.S. citizens and journalists to access and to communicate information and ideas. As I have argued elsewhere, ${ }^{90}$ the First Amendment's

\footnotetext{
88 See text accompanying notes 90-95.

89 See The Advisory Council to Google On the Right to Be Forgotten (Feb. 6, 2015) [hereinafter Google Advisory Report], https://static.googleusercontent.com/media/archive.google.com/en//advisoryc ouncil/advisement/advisory-report.pdf [https://perma.cc/C8D8-9J9L]. The Council's proposed full list of criteria that Google should consider in implementing the Google Spain decision were: (1) the data subject's role in public life (with private figures meriting greater privacy protection than public figures); (2) the nature of the information (with information in the public interest-such as information relevant to political disclosure or relating to criminal activity-meriting greater free speech protections); (3) the source of the content and the motivation to publish it (with information provided by recognized bloggers or professional journalistic entities meriting greater free speech protections); and (4) in cases involving criminal activity, the severity of the crime and the time that has elapsed since the crime occurred (with the recentness and severity of crimes militating against delisting).

90 Dawn Carla Nunziato, Forget About It? Harmonizing European and American Protections for Privacy, Free Speech, and Due Process, in PRIVACY AND POWER: A Transatlantic Dialogue In THE SHadow OF THE NSA-AfFair, 314 (Russell A. Miller, ed., 2016).
} 
strongest protections extend to information on matters of legitimate public concern, as distinguished from information of purely private concern. Thus, Google's delisting of websites containing information about private figures and matters of only private concern is not necessarily incompatible with the First Amendment rights of U.S. citizens to access information on the Internet. ${ }^{91}$ While the U.S. Supreme Court has held that the state may not constitutionally punish or restrict the "publication of truthful . . . information about a matter of public significance," 92 it has also emphasized that the First Amendment's strongest protections are reserved for information on matters of public significance or concern-not on matters of private significance or concern. As the Supreme Court explained, "Speech on matters of purely private concern is of less First Amendment concern [than speech on matters of public concern]." 93 In cases involving liability for or regulation of speech on matters of private concern, the Court has ruled that "[t]here is no threat to the free and robust debate of public issues [and] there is no potential interference with a meaningful dialogue of ideas concerning self-government." 94 The Court has emphasized that "[w]hile speech [on matters of private concern] is not totally unprotected by the First Amendment . . . its protections are less stringent." 95 Accordingly, if Google were required by the French Conseil D'État to delist (and, therefore, indirectly censor worldwide) websites relating only to matters of private importance involving only private European figures, such a mandate would not necessarily be inconsistent with the First Amendment.

Google, however, in its delisting decisions has been compelled to go beyond the recommendations of the Google Advisory Council in implementing the right to be forgotten, and - as ordered by the French Data Protection Authority CNIL - has delisted and indirectly censored websites on matters of public importance to U.S. citizens. For example, Google has been compelled to delist websites involving United States judicial proceedings and court rec-

91 See, e.g., Dun \& Bradstreet, Inc. v. Greenmoss Builders, Inc. 472 U.S. 749 (1985) (holding that speech on matters of a purely private concern has less constitutional value than speech on matters of public concern); Daniel J. Solove, The Virtues of Knowing Less: Justifying Protections Against Disclosure, 53 DUKE L. J. 967, 975 (2003) (arguing that speech of private concern is less valuable than speech of public concern).

92 Smith v. Daily Mail Pub. Co., 443 U.S. 97, 107 (1979).

93 Dun \& Bradstreet, Inc., supra note 91 , at 759.

94 Id. at 760.

95 Id. 
ords indirectly censoring content that U.S. citizens have a constitutional right to access. Indeed, as the Reporters Committee on Freedom of the Press has managed to discover (notwithstanding the lack of meaningful transparency regarding Google's delisting decisions $^{96}$ and the absence of notice provided by Google to delisted websites ${ }^{97}$ ) the French Data Protection Authority CNIL recently ordered Google to delist several U.S.-based websites devoted to discussions of legal proceedings against a French citizen under the Dodd-Frank Act (a U.S. securities law). ${ }^{98}$ In addition, CNIL has

96 Although Google provides its Transparency Report on European Privacy Requests for Search Removals, this report does not provide detailed, granular information about which requests for delisting Google grants and which it denies. See Transparency Report, GOOGLE, https://www.google.com/transparencyreport/removals/europeprivacy/?hl=en [https://perma.cc/7A9Y-VMW9]. Rather, the Report only provides high level data, such as the percentage of URLs removed from its search results, a list of the most affected sites, and twenty-three examples of the types of cases in which it has granted removal requests. The latter is of particular concern, considering that Google has received and evaluated almost 700,000 requests for removal of approximately two million websites. Id. These twenty-three examples are general and merely provide such information as: "After we removed a news story about a minor crime, the newspaper published a story about the removal action. The [United Kingdom] Information Commissioner's Office ordered us to remove the second story from search results for the individual's name. We removed the page from search results for the individual's name." Id. As other commentators have noted, "Beyond anecdote, we know very little about what kind and quantity of information is being delisted from [Google's] search results, what sources are being delisted and on what scale, what kinds of requests fail and in what proportion, and what are Google's guidelines in striking the balance between individual privacy and freedom of expression interests." See Ellen Goodman, Open Letter to Google from 80 Internet Scholars: Release RTBF Compliance Data, MEDIUM (May 13, 2015), https://medium.com/@ellgood/open-letter-to-google-from-80-internetscholars-release-rtbf-compliance-data-cbfc6d59f1bd\#.ciqjk77th [https:/ / perma.cc/Z2M9-29XU].

97 As discussed infra, the European advisory body on data protection and privacy-the Article 29 Data Protection Working Party-has determined that search engine operators should not inform content providers about decisions to remove access to websites before or even after the search engine operator has decided to remove access to the website. According to the Article 29 Data Protection Working Party Guidelines, "Search engines should not as a general practice inform the webmasters of the pages affected by de-listing of the fact that some webpages cannot be acceded from the search engine in response to specific queries ... . No provision in EU data protection law obliges search engines to communicate to original webmasters that results relating to their content have been de-listed. Such a communication is in many cases a processing of personal data and, as such, requires a proper legal ground in order to be legitimate." See Article 29 Data Prot. Working Party Guidelines, supra note 50, at 10.

98 As the Reporters Committee for Freedom of the Press set forth in its voluntary intervention in the CNIL $v$. Google case:

The CNIL has ordered the delisting of links to U.S. websites containing court records and news coverage of court proceedings. For example, the 
ordered Google to delist websites discussing a (public) Minnesota Court of Appeals decision against a French citizen. ${ }^{99}$ The global implementation of the European right to be forgotten-which would render inaccessible via Google and other search engines websites like these involving U.S. judicial proceedings and court decisions-would directly conflict with the First Amendment rights of U.S. citizens and members of the press to access such matters of public importance, ${ }^{100}$ as I discuss further below.

CNIL recently ordered the delisting of six websites originating in the U.S. - all involving legal action against a complainant under the DoddFrank Act, a U.S. securities industry law .... The links, either describing or displaying official court decisions, bear no connection to France other than through the French nationality of the defendant. The defendant's employer is a New York-based company, and the allegations against him pertain to acts he committed outside of France as chief executive officer of that New York-based company ..... In addition, the CNIL ordered Google to delist a link to a public Minnesota Court of Appeals decision, where the website's sole association with France was the complainant's nationality. The decision was considered so important to the people of Minnesota that it was made available on the Minnesota government's website.

See Reporters Committee for Freedom of the Press, French Council of State Litigation Department Voluntary Submission Intervention in Support of the Petition Submitted by Google Inc. and Against La Commission Nationale Informatique et Libertes (CNIL) in Support of Motion No. 399.922, at 13-14 https://www.rcfp.org/sites/default/files/20161104-Google-v-CNIL.pdf [https://perma.cc/3TB8-UT47].

99 Id.

100 CNIL's efforts to compel Google to implement the European right to be forgotten globally is reminiscent of the dispute between two convicted German murderers and Wikipedia that involved the balance of Germany's privacy laws against freedom of expression. That dispute involved the attempt by Wolfgang Werle and Manfred Lauber - who were convicted and served time for the murder of famous German actor Walter Sedlmayr - to have their names removed from electronic news archives and media websites that accurately reported on their prosecution and conviction for the murder. Referencing a German court decision that held that individuals have the right to no longer have their convictions reported, Werle and Lauber brought suit against several media outlets, including Der Spiegel and Wikipedia, claiming that their names must be removed from the articles on these online media websites. The Hamburg Court of First Instance granted the relief that Werle and Lauber sought, holding that the continued online publication of the names of the murderers violated their privacy rights and ordering the removal of their names from the subject articles. See, e.g., Wolfgang Werlé and Manifred Lauber, WIKIPEDIA, https://en.wikipedia.org/wiki/Wolfgang_Werl\%C3\%A9_and_Manfred_Lauber (last visited June 20, 2017) [https://perma.cc/B5T7-RG4H]. While the German Wikipedia site complied with the Hamburg Court's decision, the U.S. version of the Wikipedia site did not, contending that it had a First Amendment right to continue to publish these individuals' names in connection with its articles on the murder. Wikimedia (Wikipedia's parent company) appealed the Hamburg Court's decision to the German Constitutional Court. That Court reversed, ruling 
U.S. First Amendment jurisprudence has consistently recognized that the First Amendment's strongest protections extend to matters of public importance and to matters involving public figures, and especially to those matters that go to the heart of selfgovernance, including judicial proceedings. The First Amendment provides individuals with the right to access information concerning government decision-making and, in particular, with access to judicial records and judicial proceedings. 101 Court decisions and court orders are generally publicly available so that individuals can hold the government properly accountable for its judicial decisionmaking. Granting individuals access to information regarding judicial proceedings is essential for individuals to serve as effective checks on the government. 102 Oliver Wendell Holmes, then a Justice on the Massachusetts Supreme Court, recognized in 1884 that members of the public in a democracy must enjoy the right of access to civil trial proceedings, which is rooted in the principles of democratic government. As Holmes explained:

It is desirable that the trial of [civil] causes should take place under the public eye . . . because it is of the highest moment that those who administer justice should always act under the sense of public responsibility, and that every citizen should be able to satisfy himself with his own eyes as to the mode in which a public duty is performed. ${ }^{103}$

The modern Supreme Court has recognized that members of the public and the press have a First Amendment right of access to judicial proceedings and has held in particular that "a presumption of openness inheres in the very nature of a criminal trial under our

in favor of Wikimedia and holding that the lower court's decision ordering Wikipedia to remove the convicted murderers' names from its articles would violate the constitutional guarantee of freedom of the press. See, e.g., Judith Bruhn, Does A Murderer Have the Right to Be Forgotten?, FREE SPEECH DeBATE (Nov. 16, 2012), http:/ / freespeechdebate.com/en/case/does-a-murderer-have-the-right-to-beforgotten/ [https://perma.cc/LK42-9X5P] (questioning whether an individual's right to be forgotten should take priority over the public's right to know about the individual's past, specifically involvement in past crimes).

101 In re Globe Newspaper Co., 729 F.2d 47, 52 (1st Cir. 1984) (establishing a First Amendment right of access to records submitted in connection with criminal proceedings); Oregon Publ'g Co. v. U.S. District Court, 920 F.2d 1462 (9th Cir. 1990) (extending qualified right of access to plea agreements and related documents in criminal cases).

102 See Globe Newspaper Co. v. Pokaski, 868 F.2d 497, 502 (1st Cir. 1989); In re Globe Newspaper Co., 729 F.2d at 52; United States v. Antar, 38 F.3d 1348 1359-60 (3d Cir. 1994).

103 Cowley v. Pulsifer, 137 Mass. 392, 394 (1884). 
system of justice." 104 The Court has explained that our several First Amendment freedoms - the freedom of speech and of the press, the right of the people peaceably to assemble and to petition the Government for a redress of grievances - "share a common core purpose of assuring freedom of communication on matters relating to the functioning of government," and that this purpose is advanced by public and press access to court proceedings. All court proceedings, both criminal ${ }^{105}$ and civil, ${ }^{106}$ are presumed to be open and accessible to the public. ${ }^{107}$ This right of access is not limited to attending court proceedings but also extends to access to court documents. As the Supreme Court has explained, the First Amendment provides a right of access to court documents to promote "the free discussion of governmental affairs," 108 so as to "ensure that the individual citizen can effectively participate in and contribute to our republican system of self-government." 109 Restrictions on public access to information such as court records, court documents, and other government records, as well as restrictions on the ability of the press to publish information regarding such information, are therefore presumptively incompatible with the First Amendment.

Although, as discussed above, the right to be forgotten is not necessarily incompatible with the freedoms guaranteed by the First Amendment, this right has been implemented by Google - at the request of French data subjects and French Data Protection Author-

104 Richmond Newspapers, Inc. v. Virginia, 448 U.S. 555, 573 (1980).

105 All stages of criminal proceedings are presumed to be accessible to the public. The public's access will only be restricted if the court finds that the defendant's constitutional right to a fair trial is threatened. Press-Enterprise v. Superior Court, 464 U.S. 501, 511 (1984); Press-Enterprise v. Superior Court, 478 U.S. 1, 11 (1986).

106 All civil court proceedings are presumed to be open and accessible to the public. A court will only restrict the public's access to civil court proceedings if it finds that doing so serves an overriding public interest, that the public interest will be prejudiced in the absence of closure, that the closure is narrowly tailored to serve that interest, and that there is no less restrictive means to serve that overriding public interest. Further, the court must give the public notice before it issues an order restricting the public's access to a civil court proceeding. See NBC Subsidiary, Inc. v. Superior Court, 20 Cal. 4th 1178 (1999) (vacating lower court decision to restrict media outlets because there were no identified proceedings that would or did contain information justifying closure, and there were less restrictive means of achieving a fair trial).

107 See, e.g., Richmond Newspapers, Inc. v. Virginia, 44 U.S. 555 (1980); Globe Newspaper Co. v. Superior Court for Norfolk County, 457 U.S. 596 (1982).

108 Globe Newspaper Co. v. Superior Court, 457 U.S. at 604 (citing Mills v. Alabama, 384 U.S. 214, 218 (1996)).

109 Id. 
ity CNIL - in ways that are incompatible with First Amendment freedoms by delisting websites involving U.S. judicial proceedings and court decisions. If the French Conseil d'État were to uphold CNIL's decision requiring Google to globally remove links to websites that host items like these on all of Google's domains including Google.com, such a decision would directly conflict with the rights of United States citizens and members of the press under the First Amendment to access this information. This is especially problematic given the extent to which French citizens avail themselves of requests to delist websites from search engines like Google. Although French citizens make up only $13 \%$ of the population of the European Union, requests from French citizens account for onethird of the requests to delist that Google has received to date and Google has granted $49 \%$ of the delisting requests that it has received from French citizens. ${ }^{110}$ If French citizens persist in demanding that Google delist websites, and if Google were required to implement such delisting globally across all of its domains, French (and other European) citizens would be able to exercise unprecedented and unwarranted influence over the ability of other citizens-including United States citizens - to access information on the Internet that they have a constitutional right to access.

The recent U.S. Second Circuit case of Martin v. Hearst ${ }^{111}$ underscores the pre-eminent First Amendment value of ensuring public access to information about criminal proceedings and protecting the right of the press - including the online press - to publish information about such proceedings, even under circumstances in which aspects of the proceedings had been "forgotten" or erased subject to a state expungement law. Martin $v$. Hearst involved an arrestee's attempt to implement a version of the right to be forgotten in the United States, premised upon Connecticut's Erasure Statute, ${ }^{112}$ which requires that criminal records related to an arrest be destroyed if the individual is subsequently found not guilty or pardoned or if the charges are dropped or "nolled" (i.e., subject to a nolle prosequi decision by the prosecutor or dismissed) and after which an arrestee is "deemed to have never been arrested within

110 In its latest Transparency Report, Google indicates that it has received 221,561 requests for delisting from French citizens, out of a total of 685,240 requests from citizens throughout the European Union. See Transparency Report, European Privacy Requests for Search Removals, Google, https://www.google.com/transparencyreport/removals/europeprivacy/?hl=en (last updated June 19, 2017) [https:// perma.cc/P5P7-DUD2].

111777 F. 3d 546 (2d Cir. 2015).

112 CONN. Gen. STAT. § 54-142a(e)(3) (2017). 
the meaning of the general statutes with respect to the proceedings so erased[.]").113 In this case, Lorraine Martin and her two sons were arrested after police found drugs and drug paraphernalia upon a search of her home. A few weeks after her arrest, several local newspapers published truthful and accurate articles reporting upon her arrest. The state ultimately decided not to pursue its case against Martin and a nolle prosequi decision was entered, which entitled Martin to have her arrest records erased pursuant to the state Erasure Statute. After her arrest records were erased pursuant to the statute, Martin requested that the newspapers remove the accounts of her arrest from their news websites arguing that the statute requires the newspapers to give full effect to the statute's mandate that she is "deemed to have never been arrested . . . with respect to the proceedings so erased[.]"114 When the newspapers refused to remove the accounts of her arrest from their websites, Martin sued them for defamation, negligent infliction of emotional distress, and related invasion of privacy claims. ${ }^{115}$

In rejecting Martin's defamation, negligent infliction of emotional distress, and related invasion of privacy claims, the Second Circuit explained that the truth of the articles provided an unassailable defense for the newspapers' accurate reporting on Martin's arrest and that the newspapers had a First Amendment right to publish the accounts in the first place-as well as to maintain the online news archives of such accounts. Construing the state Erasure Statute, the Second Circuit explained:

The statute creates legal fictions, but it does not and cannot undo historical facts or convert once-true facts into falsehoods. Neither the Erasure Statute nor any amount of wishing can undo that historical truth . . . Because there is no dispute that the articles published by the Defendants accurately report Martin's arrest, her various publication-related tort claims necessarily fail. Martin's claims for libel and placing another in a false light fail because the articles do not contain falsehoods. Her claim for negligent infliction of emotional distress fails because there is nothing negligent about publishing a true and newsworthy article. ${ }^{116}$

The court explained that to hold the newspaper liable for any

113 Id.

114 Id.

115 Martin v. Hearst Corp., 777 F. 3d 546, 551 (2nd Cir. 2015).

116 Id. at 551-552. 
of these defamation or privacy torts would violate the newspaper's rights under the First Amendment. It explained that if a news organization "lawfully obtains truthful information about a matter of public significance, then state officials may not constitutionally punish publication of the information, absent a need to further a state interest of the highest order." 117 The court concluded that, despite Martin's privacy and reputational interests in securing the erasure of her arrest records from the state's records, the newspaper nonetheless still enjoyed the right to publish truthful and accurate news articles on such matters and members of the public enjoy a concomitant right to access such content on the Internet.

In sum, the global implementation of the right to be forgottenas the French Data Protection Authority is now demanding before France's highest administrative court-coupled with the mandate that Google indirectly censor websites on matters of public importance to U.S. citizens (including on matters relating to U.S. judicial proceedings and court records) is not only an unwarranted extraterritorial extension of European jurisprudence to prescribe, but would also result in a direct conflict with the First Amendment rights of U.S. citizens and members of the press.

\section{THE EUROPEAN UNION'S NEW PRIVACY LAW - THE GENERAL DATA PROTECTION REGULATION - WILL ONLY INCREASE THE PROBLEMS WITH THE RIGHT TO BE FORGOTTEN}

The various issues and problems analyzed above in connection with the 1995 EU Data Protection Directive and its interpretation by the European Court of Justice and European courts to support the right to be forgotten will only be exacerbated when the Directive is superseded by the General Data Protection Regulation. In May 2018, the EU Data Protection Directive, under which the original right to be forgotten decision was recognized, was replaced by the General Data Protection Regulation (GDPR), a massive overhaul of European data privacy regulation. ${ }^{118}$ This Regula-

117 Id. See also Gates v. Discovery Commc'ns, Inc., 101 P.3d 552 (Cal. 2004) (explaining that news publishers cannot be held liable for invasion of privacy for reporting on plaintiff's criminal record and criminal activities that occurred more than a dozen years prior).

118 This Regulation, which was adopted in April 2016, entered into application on May 25, 2018, after a transition period of two years. In contrast to the 1995 EU Data Protection Directive, the GDPR - because it is a Regulation rather than a Directive-does not require the European national governments to pass any ena- 
tion, adopted in April 2016, entered into application on May 25, 2018, after a two-year transition period. Unlike the 1995 EU Data Protection Directive, the Regulation does not require national governments to pass any enabling legislation to enforce its terms since, as a Regulation, it is self-executing. The General Data Protection Regulation, which updates and overhauls the 1995 EU Data Protection Directive, expressly provides that it extends to all foreign companies that process the data of EU residents, regardless of where those companies are located. Unlike the 1995 EU Data Protection Directive, the Regulation expressly applies to organizations based outside the European Union if they process the personal data of EU residents. The Regulation harmonizes the data protection regulations throughout the EU and imposes a strict compliance regime on all foreign companies that control or process EU residents' data. Importantly, the Regulation imposes substantial fines-EUR 20 million or $4 \%$ of a company's total worldwide annual turnover of the preceding year, whichever is higher-on data controllers (like Google) who fail to comply with the Regulation's strict terms for the protection of data. ${ }^{119}$

Article 17 of the General Data Protection Regulation-entitled "Right to erasure ('right to be forgotten')" - specifically grants European data subjects the right to require that data controllers erase and cease from redistributing personal information about the data subject without undue delay, if the data are no longer necessary in relation to the purposes for which they were collected or processed, if the data subject withdraws consent on which the processing was based, or where there is no legal ground for the processing. This Article further requires data controllers to inform downstream data processors of the data subject's request for erasure. The applicable provisions from the Regulation and their complex interactions are as follows:

\section{Article 17 Right to erasure ('right to be forgotten')}

bling legislation to enforce its terms and will go into effect automatically upon its effective date. See Daphne Keller, Intermediary Liability and User Content Under Europe's New Data Protection Law, STAN. L. SCH.: THE CTR. FOR INTERNET AND SOC'Y (Oct. 8, 2015), http://cyberlaw.stanford.edu/blog/2015/10/intermediaryliability-and-user-content-under-europe $\%$ E2\% $80 \% 99$ s-new-data-protection-law [https://perma.cc/G5X6-UY2N].

119 See General Data Protection Regulation [hereinafter GDPR] 2016/679, art. 83, 2016 O.J. (L 119) 1 (EU), available at http://eur-lex.europa.eu/legalcontent/EN/TXT/PDF/?uri=OJ:L:2016:119:FULL\&from=EN

[https://perma.cc/6ATJ-5RM9] (detailing the fines to be imposed on data controllers who fail to comply with the Regulation's strict terms). 
1. The data subject shall have the right to obtain from the controller the erasure of personal data concerning him or her without undue delay and the controller shall have the obligation to erase personal data without undue delay where one of the following grounds applies:

(a) the personal data are no longer necessary in relation to the purposes for which they were collected or otherwise processed;

(b) the data subject withdraws consent on which the processing is based according to point (a) of Article 6(1), ${ }^{120}$ or point (a) of Article $9(2)^{121}$ and where there is no other legal ground for the processing;

(c) the data subject objects to the processing pursuant to Article $21(1)^{122}$ and there are no overriding legitimate grounds

120 Id. Article 6(1)(a) provides that processing of personal data shall be lawful only if and to the extent that "the data subject has given consent to the processing of their personal data for one or more specific purposes."

121 Id. Article 9(2)(a) provides that the prohibition set forth in Article 9(1) on the processing of special categories of personal data-defined as data revealing "racial or ethnic origin, political opinions, religious or philosophical beliefs, or trade union membership, and the processing of genetic data, biometric data for the purpose of uniquely identifying a natural person, data concerning health or data concerning a natural person's sex life or sexual orientation" - shall not apply "if the data subject has given explicit consent to the processing of those personal data for one or more specified purposes, except where Union or Member State law provide that the prohibition referred to in paragraph 1 may not be lifted by the data subject."

122 Id. Article 21, the Right to Object, provides in Section 1:

The data subject shall have the right to object, on grounds relating to his or her particular situation, at any time to processing of personal data concerning him or her which is based on point (e) or (f) of Article 6(1), including profiling based on those provisions. The controller shall no longer process the personal data unless the controller demonstrates compelling legitimate grounds for the processing which override the interests, rights and freedoms of the data subject or for the establishment, exercise or defense of legal claims.

Article 6, Lawfulness of Processing, provides in its Section(1)(e) and (f) that processing shall be lawful only if and to the extent that:

(e) processing is necessary for the performance of a task carried out in the public interest or in the exercise of official authority vested in the controller;

(f) processing is necessary for the purposes of the legitimate interests pursued by the controller or by a third party, except where such interests are overridden by the interests or fundamental rights and freedoms of the data subject which require protection of personal data, in particular where the data subject is a child. 
for the processing, or the data subject objects to the processing pursuant to Article 21(2) ${ }^{123}$;

(d) the personal data have been unlawfully processed;

(e) the personal data have to be erased for compliance with a legal obligation in Union or Member State law to which the controller is subject;

(f) the personal data have been collected in relation to the offer of information society services referred to in Article $8(1) .{ }^{124}$

2. Where the controller has made the personal data public and is obliged pursuant to paragraph 1 to erase the personal data, the controller, taking account of available technology and the cost of implementation, shall take reasonable steps, including technical measures, to inform controllers which are processing the personal data that the data subject has requested the erasure by such controllers of any links to, or copy or replication of, those personal data.

3. Paragraphs 1 and 2 shall not apply to the extent that processing is necessary:

(a) for exercising the right of freedom of expression and information;

(b) for compliance with a legal obligation which requires processing by Union or Member State law to which the controller is subject or for the performance of a task carried out in the public interest or in the exercise of official authority vested in the controller;

(c) for reasons of public interest in the area of public health

123 Id. Article 21, the Right to Object, provides in Section 2:

Where personal data are processed for direct marketing purposes, the data subject shall have the right to object at any time to processing of personal data concerning him or her for such marketing, which includes profiling to the extent that it is related to such direct marketing.

124 Id. Article 8(1) provides: “Where point (a) of Article 6(1) applies [(i.e., where the data subject has given consent to the processing of his or her personal data for one or more specific purposes)] in relation to the offer of information society services directly to a child, the processing of the personal data of a child shall be lawful where the child is at least 16 years old. Where the child is below the age of 16 years, such processing shall be lawful only if and to the extent that consent is given or authorized by the holder of parental responsibility over the child." 
in accordance with points (h) and (i) of Article 9(2) ${ }^{125}$ as well as Article 9(3) ${ }^{126}$;

(d) for archiving purposes in the public interest, scientific or historical research purposes or statistical purposes in accordance with Article $89(1)^{127}$ in so far as the right referred to in paragraph 1 is likely to render impossible or seriously impair the achievement of the objectives of that processing; or

(e) for the establishment, exercise or defense of legal claims.

125 Id. Article 9(2)(h) and (i) allow for the processing of special categories of personal data-defined as data revealing "racial or ethnic origin, political opinions, religious or philosophical beliefs, or trade union membership, and the processing of genetic data, biometric data for the purpose of uniquely identifying a natural person, data concerning health or data concerning a natural person's sex life or sexual orientation" - when " $(\mathrm{h})$ processing is necessary for the purposes of preventive or occupational medicine, for the assessment of the working capacity of the employee, medical diagnosis, the provision of health or social care or treatment or the management of health or social care systems and services on the basis of Union or Member State law or pursuant to contract with a health professional and subject to the conditions and safeguards referred to in paragraph 3; (i) processing is necessary for reasons of public interest in the area of public health, such as protecting against serious cross-border threats to health or ensuring high standards of quality and safety of health care and of medicinal products or medical devices, on the basis of Union or Member State law which provides for suitable and specific measures to safeguard the rights and freedoms of the data subject, in particular professional secrecy."

126 Id. Article 9(3) allows for the processing of special categories of personal data - data revealing "racial or ethnic origin, political opinions, religious or philosophical beliefs, or trade union membership, and the processing of genetic data, biometric data for the purpose of uniquely identifying a natural person, data concerning health or data concerning a natural person's sex life or sexual orientation" - "when those data are processed by or under the responsibility of a professional subject to the obligation of professional secrecy under Union or Member State law or rules established by national competent bodies or by another person also subject to an obligation of secrecy under Union or Member State law or rules established by national competent bodies."

127 Id. Article 89, entitled, "Safeguards and derogations relating to processing for archiving purposes in the public interest, scientific or historical research purposes or statistical purposes," provides in Section 1:

Processing for archiving purposes in the public interest, scientific or historical research purposes or statistical purposes, shall be subject to appropriate safeguards, in accordance with this Regulation, for the rights and freedoms of the data subject. Those safeguards shall ensure that technical and organizational measures are in place in particular in order to ensure respect for the principle of data minimization. Those measures may include pseudonymisation provided that those purposes can be fulfilled in that manner. Where those purposes can be fulfilled by further processing which does not permit or no longer permits the identification of data subjects, those purposes shall be fulfilled in that manner. 
Although the above language from the Regulation nominally provides the data controller with a "freedom of expression" defense to the data subject's erasure request, other aspects of the Regulation-including the exorbitant fines for noncompliance and the "necessity" caveat on the freedom of expression defense-will likely skew the balance in favor of the data subject's removal rights and against the data controller's right to freedom of expression. Other procedural aspects of the Regulation's contemplated review and removal process will also tilt the balance in favor of erasure and against freedom of expression. As data protection expert Daphne Keller explains, the Regulation's terms-including the requirement that the data controller take down personal data immediately (while evaluating the merits of the data subject's claim) and the burden of proof placed on the data controller, coupled with the exorbitant financial penalties for noncompliance-will create an unprecedented imbalance in the Internet ecosystem in favor of data subjects' erasure requests and against the right to access and right to publish information on the Internet, 128 as I examine below.

First, Article 12 of the Regulation - in its provision of guidelines for data controllers like Google for facilitating the exercise of data subjects' rights under Article 17's right to erasure/right to be forgotten-provides that controllers shall act "without undue delay," which in general means "within one month of receipt of the [data subject's] request." 129 Article 12 further provides that the data controller may refuse to take action on the data subject's right to be forgotten/right to erasure requests only if the requests from the data subject are "manifestly unfounded or excessive." 130 The burden of proving that the data subject's requests are "manifestly unfounded or excessive," however, falls on the data controller. If the data controller is disinclined to grant the data subject's removal request-because the controller believes the request to be manifestly unfounded or excessive, for example - the data subject nonetheless has the right to secure the temporary takedown of his or her personal data from all public websites under Article 18 of the Regulation. That is, the default under the Regulation is that the data sub-

128 See Daphne Keller, The Final Draft of Europe's “Right to Be Forgotten" Law, Stan. L. Sch.: The Ctr. for Internet and Soc'y (Dec. 17, 2015) http:/ / cyberlaw.stanford.edu/blog/2015/12/final-draft-europes-right-beforgotten-law [https://perma.cc/FM2G-T7BE] (explaining that the Regulation's terms will create an unprecedented balance on the Internet in favor of data subjects' erasure requests).

129 See GDPR, supra note 119, at art. 12(3).

$130 \quad I d$. 
ject has the right to have the websites containing his or her personal data taken down during the pendency of the data controller's consideration of the data subject's request. As Daphne Keller explains in interpreting the interplay of these Articles, search engines like Google "must take the challenged content offline immediately, before weighing the public interest [in keeping the website up] and perhaps before even looking at the content." 131 In other words, a search engine or other data controller is required to restrict the processing of data pending its verification of whether the legitimate grounds of the data controller override those of the data subject. ${ }^{132}$

Importantly, one essential element that is conspicuously absent from the Regulation is the provision of notice and an opportunity to be heard for the website publisher or speaker whose speech is being erased or delisted. The Regulation's contemplated regime for data controllers' evaluation of erasure/right to be forgotten requests does nothing to remedy the procedural defects in the decision-making process contemplated by the European Court of Justice's right to be forgotten regime under the 1995 EU Data Protection Directive, under which no notice or opportunity to be heard is to be granted to the affected speakers or publishers, either before or after a decision has been made to delist their websites. ${ }^{133}$ As I have argued elsewhere, to the extent that the right to erasure/right to be forgotten is implemented in a manner that fails to accord notice or an opportunity to be heard to speakers or publishers whose content is to be indirectly censored by a search engine, such a process is radically deficient from the perspective of fundamental shared notions of due process principles. ${ }^{134}$ Fundamental

131 Id.

132 See Keller, supra note 128.

133 Under the decision-making regime contemplated under the original right to be forgotten decision, search engines like Google are prohibited from providing notice or an opportunity to be heard to websites whose content a data subject requests to be delisted. The EU Article 29 Working Party has also concluded that search engines should not provide notice to websites whose content is delisted and that there is no legal basis for providing such notice. In its Guidelines, the Working Party indicates:

Communication to website editors on the de-listing of specific links. Search engines should not as a general practice inform the webmasters of the pages affected by de-listing of the fact that some web pages cannot be acceded from the search engine in response to a specific name-based query. There is no legal basis for such routine communication under EU data protection law.

See Article 29 Data Prot. Working Party Guidelines, supra note 50, at 9.

134 See Nunziato, supra note 90, at 304 (explaining that the process through which Google has implemented the Court's decision fails to provide the proce- 
shared notions of due process of law require that an individual be granted notice and the opportunity to be heard and to state her case to an impartial decision-maker before she is deprived of her fundamental rights - including her right to freedom of expression. The U.S. Constitution's Due Process provisions, for example, require that any such deprivation of individuals' right to freedom of expression occur only as a result of a fair, independent, and impartial decision-making process in which affected parties are provided with meaningful notice and an opportunity to be heard before a decision is rendered. ${ }^{135}$ Before the state deprives an individual of a substantial liberty interest such as the right to freedom of expression, the individual must be accorded: adequate notice of the basis for government action; an opportunity to be heard by the decisionmaker; and a determination by an impartial decision-maker. Importantly, when the state seeks to authorize a restriction on an individual's freedom of expression, prior notice to that individual must be provided ("An elementary and fundamental requirement of due process in any proceeding . . . is notice reasonably calculated, under all the circumstances, to apprise interested parties of the . .. action and afford them an opportunity to present their objections."). ${ }^{136}$ Absent such procedural safeguards, state-authorized restrictions on expression are unconstitutional. These fundamental due process principles are recognized in the governing documents of the European Union as well. With respect to the determination of civil rights and obligations, Article 6 of the European Convention on Human Rights provides for the general right to procedural fairness, including a hearing before a fair, independent, and impartial tribunal that provides a reasoned judgment. ${ }^{137}$ In each of these foundational documents and instruments, procedural due process rights and the right to independent, impartial, and fair judicial determinations of one's civil and human rights are recognized as necessary for the meaningful protection of substantive rightsincluding the right to freedom of expression - in the European Union. The European Court of Human Rights has emphasized the

dural safeguards necessary for the protection of speech under fundamental notions of due process shared by both the US and the European legal systems).

1351 Ronald D. Rotunda \& John E. Nowak, Treatise On Constitutional Law: Substance And Procedure § 17.4(c) (5th ed. 2012).

136 Mullane v. Central Hanover Bank \& Trust Co., 339 U.S. 306, 314 (1950).

137 European Convention, supra note 39, at art. 6(1) ("In the determination of his civil rights and obligations ... everyone is entitled to a fair and public hearing within a reasonable time by an independent and impartial tribunal established by law."). 
centrality of the rights of procedural due process articulated in Article 6 of the European Convention and has affirmed that an expansive view of these procedural rights is fundamental to protecting civil and human rights. ${ }^{138}$

Because the General Data Protection Regulation charges the search engine/data controller with making the decision whether to grant the data subject's request to delist or erase the website(s) at issue without hearing from one side (i.e., the publisher or speaker of the content), this process is severely deficient from the perspective of fundamental principles of due process shared by both the United States and the European Union and will undoubtedly lead to a lopsided consideration of the merits of the privacy versus free speech interests at stake. This factor-coupled with the exorbitant fines that can be levied against data controllers for failure to comply with the Regulation's strict erasure mandates - will likely produce an Internet ecosystem that fails to adequately balance free speech interests against competing privacy interests.

In short, rather than remedying the imbalance between privacy and free speech interests and the due process concerns that have developed as a result of the implementation of the Google Spain's right to be forgotten decision under the 1995 European Union Data Protection Directive, the General Data Protection Regulation exacerbates such problems and skews the playing field and the Internet ecosystem even further in favor of censorship in the name of privacy and against freedom of expression on the Internet.

\section{THE EXPANSION OF THE RIGHT TO BE FORGOTTEN BEYOND THE MEMBER STATES OF THE EUROPEAN UNION}

The expansion of the scope and geographical reach of the right to be forgotten from the limited scope and reach of the decision as originally recognized by the European Court of Justice in 2014 is problematic in a variety of ways, as I have analyzed above. Yet, the difficulties that the right to be forgotten poses for the right to freedom of expression online will only multiply as other countries adopt versions of that right and as they attempt (as France has done) to implement their version of the right beyond their borders. The right to be forgotten is no longer confined to the member states of the European Union, and, in the three years since it was recog-

138 See Delcourt v. Belgium, 1 Eur. Ct. H.R. 355 (1970) (cited in RICHARD Clayton \& Hugh Tomlinson, The Law of Human Rights 621-22 (2009)). 
nized by the European Court of Justice, has expanded to other countries in Europe as well as to countries in Asia and the Americas, including Mexico, Japan, Russia, Colombia, and India.

Mexico. In 2014, Mexico adopted a framework similar to that adopted by the European Court of Justice in its Google Spain decision in a case decided by Mexico's National Institute for the Access to Information (INAI) under its Federal Personal Data Protection Processed by Private Entities Act.139 Under this Act, every person has the right to request the cancellation of his or her personal data and the right to oppose its processing. ${ }^{140}$ Article 25 of the Act grants data subjects the right to request that a data controller stop processing and that the data controller (partially or completely) erase his or her personal data. Once a data subject makes a request to the data controller to cancel the processing of his or her personal data, the data controller must stop processing such personal data immediately, subject to certain limited exceptions. ${ }^{141}$ In addition, Article 27 of the Act grants data subjects the right to prevent a data controller from continuing to process the data subject's personal data for any legitimate reason. In a recent landmark case, Carlos Sanchez de la Pena, a Mexican businessman and data subject who objected to negative but truthful comments about his business

139 See Sánchez de la Peña v. Google México, S. de R.L., PPD.0094/14 (Mex.). See also, Background: The Right to Be Forgotten in National and Regional Contexts, International Federation of Library Associations and Institutions, http://www.ifla.org/files/assets/clm/statements/rtbf_background.pdf

[https://perma.cc/GU3L-EK4H]; Laurence Iliff, Google Wages Free-Speech Fight in Mexico, WALL ST. J. (May 27, 2015), http://www.wsj.com/articles/google-wagesfree-speech-fight-in-mexico-1432723483 [https://perma.cc/9C4M-NN47] (discussing the decision).

140 See Reglamento de la Ley Federal de Protección de Datos Personales en Posesión de los Particulares (Regulations of the Federal Law on the Protection of Personal Data in Held by Private Parties) [RLFPDPPP], Art. 22, 28, Diario Oficial de la Federación [DOF] 21-12-2011 (Mex.).

141 Reglamento de la Ley Federal de Protección de Datos Personales en Posesión de los Particulares (Regulations of the Federal Law on the Protection of Personal Data in Held by Private Parties) [RLFPDPPP], Art. 26, Diario Oficial de la Federación [DOF] 05-07-2010 (Mex.) (providing that the data controller is not required to cancel the personal data if:

The personal data is necessary to fulfill a contract, agreement or providing of services between the controller and the data subject; the processing is required by law; the cancellation or erasure could undermine a criminal or administrative investigation or could prevent the imposition of criminal or administrative sanctions; the personal data is necessary to protect a data subject's legal interest or to fulfill a legal obligation or agreement; or the personal data used for health and medical care, when the data is processed by a doctor or health care professional.). 
dealings on various websites (including discussions of the government's bailout of his business for various bad loans), argued that Google should be required to delist these articles, notwithstanding the fact that they were truthful and that they arguably involved matters of public concern. The National Institute for the Access to Information agreed with de la Pena and ordered Google to remove the search results upon a search of de la Pena's name on Google's Mexican search domain. ${ }^{142}$ This decision suggests that Mexico's newly-enshrined right to be forgotten will be implemented in a manner that fails to account for the right to access speech on matters of public importance and public concern.

Japan. Only a few months after the European Court of Justice's Google Spain decision, a Japanese court issued the country's first right to be forgotten decision. In October 2014, the Tokyo District Court issued an injunction ordering Google to delist websites relating to the past criminal activity of a Japanese man. Since then, Yahoo! Japan has implemented a procedure through which Japanese individuals can request that Yahoo! Japan delist websites that contain information that they believe interferes with their right to privacy. ${ }^{143}$ Yahoo! Japan will delist websites that contain information about individuals' sensitive information that individuals seek to have removed, including their past criminal offenses.

Russia. The Russian Federation recently enacted its right to be forgotten law, which came into effect on January 1, 2016. In enacting the law, Russian lawmakers referred explicitly to the European Court of Justice's Google Spain decision and borrowed from that decision's reasoning and from the underlying European Union's Data Protection Directive. ${ }^{144}$ The law grants Russian data subjects the right to request delisting from any search engine that makes available advertising directed at individuals residing in the Rus-

\footnotetext{
142 Id.

143 Yahoo Japan Sets Out Procedure for Search Result Removal, THE JAPAN TIMES (Mar. 31 , 2015),

http://www.japantimes.co.jp/news/2015/03/31/national/yahoo-japan-setsprocedure-search-result-removal/\#.Vk3wHXbnuU [https://perma.cc/ZDU5Z2Y5]. See also Juston McCurry, Japan Recognizes 'Right to Be Forgotten' of Man Convicted of Child Sex Offences, THE GuARDian (Mar. 1, 2016), https://www.theguardian.com/technology/2016/mar/01/japan-recognisesright-to-be-forgotten-of-man-convicted-of-child-sex-offences [https://perma.cc/4DGK-BVDZ].

144 See Russia: The “Right to Be Forgotten” Bill, Article 19.org (Aug. 2015), https://www.article19.org/data/files/medialibrary/38099/Full-Analysis--Russia---RTBF-Final-EHH.pdf [https://perma.cc/W55J-97NC] (analyzing the Russian "Right to be Forgotten" Bill and its compatibility with international standards of freedom of expression).
} 
sian Federation. As under the European Union's Data Protection Directive, under the Russian right to be forgotten law, data subjects are granted the right to request the delisting of websites containing information about them where the information is inaccurate, out of date, or irrelevant. ${ }^{145}$ In addition, the Russian right to be forgotten law grants data subjects a general purpose right to request the delisting of any information about them that is disseminated "contrary to Russian law," including, for example, "instructions on manufacturing of drugs, information about committing suicide, information on gambling, [and] pornography."146 Specifically, the Russian right to be forgotten law provides that search engines operators must "stop providing links to websites . . . [that are] distributed in violation of the legislation of the Russian Federation, [are] inaccurate and dated, [or] which [have] lost meaning for the application by virtue of any subsequent events or actions taken by the applicant." 147 Notably, the Russian right to be forgotten law does not provide for any exceptions to that right for matters of public interest or for public figures, 148 and, as such, will likely have harmful consequences for the free flow of information in Russia.

Colombia. Colombia's Constitutional Court has adopted a particularly problematic interpretation of the right to be forgotten, one that applies directly against the underlying websites at issue instead of merely against search engines like Google including in the context of websites' truthful and accurate reporting about a criminal prosecution. In a decision reached in 2015, the Colombian Constitutional Court granted an individual's request to de-list information about her criminal prosecution against the original news website itself and required the newspaper El Tiempo to use technical measures (such as the robots.txt file) to ensure that the web pages at issue in its news archives - which truthfully described the individual's prosecution for slave trafficking-could not be indexed by search engines. ${ }^{149}$

$145 I d$.

146 See, e.g., Ruslan Nurullaev, Right to Be Forgotten in the European Union and Russia: Comparison and Criticism, 3 L. J. OF THE HighER SCH. OF ECON., 181, 190 (2015), available

https://www.hse.ru/data/2015/10/11/1076267685/nurullaev.pdf

[https://perma.cc/GU6Q-BDMB].

147 Id.

148 See, e.g., Access Now Position Paper: Understanding the Right to Be Forgotten Globally, AccessNow.ORG., 9 (Sept. 2016), https://www.accessnow.org/cms/assets/uploads/2016/09/Access-Not-paperthe-Right-to-be-forgotten.pdf [https:// perma.cc/44XQ-F8GQ].

149 See Colombia: Constitutional Court Rules on the "Right to Be Forgotten," INT'L 
India. In early 2017, an Indian court of appeals, the Karnataka High Court of India, was the first in the nation to judicially recognize an Indian data subject's right to be forgotten. ${ }^{150}$ The court's landmark ruling recognizing the right to be forgotten is particularly problematic because it mandated the anonymization of information involving court records that were in the public domain. The case involved the interests of a woman who had previously been married, but who later sought a judicial annulment of that marriage. The father of the woman petitioned the court to remove her name from the court records involving the annulment, claiming on behalf of his daughter that the public accessibility of the court records involving the annulment of her marriage would affect her relationship with her current husband and her reputation in society. The Karnataka High Court granted the father's request to anonymize his daughter's name in the court records involving the previous request for annulment, holding that the recognition of the right to be forgotten in this instance was "in line with the trend in western countries of the 'right to be forgotten' in sensitive cases involving women in general and highly sensitive cases involving rape or affecting the modesty and reputation of the person concerned." 151 This case creates precedent for the removal of information from the public domain and from electronic court records and therefore is a particularly problematic application of the right to be forgotten.

With the recent adoption of versions of the right to be forgotten in several other countries in Europe as well as in Asia and the Americas, one-third of the world's population now lives under a regime in which search engines - and in some cases news, media, and government websites themselves - are under an obligation, directly or indirectly, to censor content that is claimed to violate the privacy rights (or, as in India's case, the modesty and reputational interests) of a complaining data subject. The expansion of the geographical scope and reach of the right to be forgotten will pose increasing dangers to the Internet ecosystem and the free flow of in-

\footnotetext{
ACAD. OF COMPARATIVE L. BLOG (Jul. 14, 2015), http:/ / iuscomparatum.info/colombia-constitutional-court-rules-on-the-right-tobe-forgotten [https:/ / perma.cc/2BA3-MKBU]; Corte Constitucional [C.C.] [Constitutional Court], mayo 15, 1995, Sentencia T-277/15 (Colom.) available at http://www.corteconstitucional.gov.co/relatoria/2015/t-277-15.htm (summarizing the Constitutional Court of Colombia's decision on the right to be forgotten).

150 Sri Vasunathan v. The Registrar General, W.P. No. 62038/2016 (Kar. Jan. 23, 2017), 2-4 (India).

151 Id. at 4.
} 
formation on the Internet.

\section{CONCLUSION}

When the European Court of Justice initially enshrined the right to be forgotten in May 2014, it created a limited right and imposed a limited remedy - one that applied only to search engines, that only mandated delisting of certain search results by search engines (not erasure or anonymization by the offending websites themselves), and that only applied to search engines' European domains. As the right to be forgotten enters its fourth year of enactment, the right has been expanded in a myriad of ways that pose grave concerns for freedom of expression on the Internet: it has been applied to require news, government, and other websites to erase and anonymize content regarding matters of public importance; it has been recognized in at least six new countries in Europe, Asia, and the Americas; and, if the French Data Protection Authority has its way, it will be implemented globally, to all searches on Google.com, for example, to censor the content accessible by Internet users across the globe, regardless of whether they live in a country that recognizes the right to be forgotten. To make matters worse, the data protection regulation that went into effect in May 2018 grants even greater rights to data subjects to secure the removal of Internet content with which they disagree, without according fundamental due process protections-notice and an opportunity to be heard - to those whose speech is to be censored. Absent greater attention to these issues, and absent the contraction of this rapidly expanding right to be forgotten, free speech on the Internet as we know it will continue to be imperiled. 